\title{
LAS DANZAS ROMANCESCAS Y EL "BAILE DEL TAMBOR" DE LA GOMERA
}

\author{
Maximiano TRAPERO
}

\begin{abstract}
Resumen: La pervivencia del romancero tradicional en la isla de La Gomera (Canarias) presenta particularidades sobresalientes si lo comparamos con el resto del mundo hispánico, tanto por la cantidad y calidad de su repertorio como por el grado de vitalidad de la tradición. Esto se debe al hecho de que el romancero sigue cumpliendo alli una función festiva. En La Gomera los romances se cantan y sirven de soporte a un baile romancesco, el más popular en la isla, el "baile del tambor", el ultimo testimonio de una antiquísima costumbre extendida por todo el terrilorio español, y de la que, fuera de La Gomera, quedan sólo recuerdos y referencias.

Choreae ad Romances et Gomerae "Tympani Saltatio"

Summarium: Poeticae compositionis Hispanicae, "romancero" dictae, superviventia in insula Gomera (Fortunata insula) singularitates supereminentes affert, reliquo ambitui Hispanico comparata, tum eius repertorii quantitate qualitateque cum traditionis vitalis vigoris gradu. Compositio Hispanica igitur ibi munus festivum implet. In insula Gomera hae compositiones canuntur et quamdam ad romances choream sustinent, in insula popularissimam, "Tympani saltationem", antiquissimi usus ultimam testificationem, omnibus finibus Hispanis prolatam, extra Gomeram autem illius indicia tantum manent.
\end{abstract}

\section{UNA DANZA ROMANCESCA DESCONOCIDA}

Las mismas palabras de sorpresa que escribió Menéndez Pidal cuando, en una tarde de julio de 1905, en el trance de una encuesta romancística en el pueblo avulense de Las Navas del Marqués, ${ }^{1}$ descubrió que los romances seguian bailándose, podriamos escribir nosotros ahora cuando, llegados a la isla canaria de La Gomera,

I La encuesta en Las Navas sirvió para "catequizar" en la recolección de romances a quien después se convertiría en uno de los mejores que ha tenido el romancero en el siglo Xx. Manuel Manrique de Lara. La descripción de esta visita a Las Navas la recoge MENEndez Pidal en varias de sus publicaciones, entre ellas en su Romancero Hispánico, II, Madrid, Espasa Calpe, 2.a ed., 1968, pp. 295-299 (En adelante cit. Rom. Hisp.). 
también en busca de romances, descubrimos que también allí, en julio de $1983,{ }^{2}$ el canto de los romances servía para la danza local. Menéndez Pidal decía entonces: "En nuestro obsequio se organizó por la tarde en la plaza el baile típico de la localidad que llamaban el baile de tres. Esperábamos ver algo curioso, pero no sospechábamos que fuese tanto como resultó". 3 Por diferencia, para nosotros nada especial se organizaba en La Gomera: ni nosotros éramos merecedores de obsequio alguno, ni los gomeros tenían por extraordinario su baile. Aquello era también un baile local. Aquello era también un baile romancesco, probablemente el último superviviente de una tradición antiquísima en que la danza se asentaba sobre el canto de un relato baladístico. Aquello era también un descubrimiento, pues aunque el baile como tal era conocido por folkloristas en general como un baile típico de $\mathrm{La}$ Gomera, probablemente de raices prehispánicas, había pasado desapercibido su carácter romancesco y por ello había sido absolutamente ignorado en los estudios del romancero. Aquello era el baile del tambor. Pero nosotros, gracias al descubrimiento de don Ramón en Las Navas del Marqués, y a los otros descubrimientos que luego le siguieron, íbamos preparados ya para recibir la sorpresa.

\section{LAS DANZAS CANTADAS}

Las danzas cantadas, o el canto danzado (la primacía de un elemento sobre el otro tiene interés sobre todo desde el punto de vista histórico, bien como canto que se aplica a una danza preexistente, bien como danza que se crea para coreografiar un canto, bien como danza y canto que surgen a la vez), han existido en España desde la antigüedad. Lo que ya no sabemos muy bien es si son producto de la civilización hispanorromana, importación de los pueblos germánicos invasores o sustrato de los primitivos pueblos peninsulares. ${ }^{4}$ Seguramente son las tres cosas juntas, es decir, una huella de una civilización

\footnotetext{
${ }^{2}$ Eso fue con motivo de una encuesta romancistica a La Gomera en el verano de 1983. con un equipo encuestador formado por mí mismo, por mi mujer, Helena Hernández Casañas y por Lothar Siemens Hernández, y de cuyos resultados extraordinarios esperamos dar noticia en nuestro Romancero de la isla de La Gomera, en prensa.

${ }^{3}$ Rom. Hisp., II, p. 296.

4. Desde una visión local impresionista se pretende ver siempre en los bailes propios los más arcaicos origenes, como si la antigüedad, por si sola, fuese certificado de garantí. Asi, por ejemplo, uno de los bailes que luego mencionaremos, el asturiano corri-corri, se identifica nada menos que como un descendiente de las pinturas rupestres de Peña Tú, en el concejo de Llanes, y superviviente, por tanto, de una cultura megalítica. Vid. Modesto G. COBAS, De Musicología Asturiana: La canción tradicional, Oviedo, IDEA, 1975, p. 8 .
} 
primitiva contaminada por civilizaciones posteriores que se va recomponiendo y adaptando a cada momento histórico. ${ }^{5}$

Con toda razón dice Menéndez Pidal: "El baile acompañado del canto es la manifestación de arte popular más completa y acabada, concurriendo en ella los instrumentos, la voz, la poesía y la rítmica coreográfica". ${ }^{6}$ Pero dqué es lo que se canta en una danza cantada? 0 lo que es lo mismo, ¿qué textos se utilizan en el canto? Por lo que respecta a la actualidad cabría decir, generalizando, que coplas, seguidillas o cualquier otro tipo de letrillas, es decir, textos líricos organizadus en una o varias estrofas que pueden alargarse o acortarse a voluntad (no, desde luego, más allá de tres o cuatro estrofas). Así podríamos citar los más famosos bailes cantados de España: las isas y las folias en Canarias, las seguidillas en La Mancha, el bolero en Castilla y Mallorca, la muñeira en Galicia, las sevillanas y el fandango en Andalucía, la jota en Aragón y en toda España. Pero no siempre fue así. "En varias naciones y en época antigua -en palabras de Menéndez Pidal- el canto que acompañaba al baile era narrativo. Por eso en algunos idiomas el vocablo balada, 'bailada', recibió el sentido de poema breve que refiere una historia o leyenda', sentido que se propagó de la lengua inglesa y alemana (ballad, ballade) a las lenguas neolatinas en el siglo XIX, por influjo del romanticismo". ${ }^{7}$ Pero los gustos cambiaron. Por lo que respecta a España, en los siglos XVI y XVII, a la par que la lírica popular influía poderosamente sobre la antigua épica, los textos líricos se convirtieron en soporte de los cantos bailados. Desde entonces -acaba Menéndez Pidal- "tan olvidada vino a quedar en todas partes la danza como canción narrativa, que hoy sólo por raro arcaismo subsiste tal uso". ${ }^{8}$ Hoy definitivamente es la canción lírica la que se baila cuando la canción sirve para bailar.

${ }^{5}$ La falta de documentación y referencias escritas sobre estos temas nos impiden precisar, pero lo que sí sabemos es que las danzas cantadas en la España medieval llegaron a la propia iglesia. Dentro de las iglesias y con motivo de los primeros autos religiosos se hacian representaciones y espectáculos, unos brillantes otros rústicos, unos vistosos otros sencillos, pero todos didácticos y moralizantes, en los que siempre habia una o varias danzas como elemento principal. La costumbre arraigó y se extendjó y llegó hasta el siglo XVII, de tal forma que no pocos de los autos religiosos que se escribieron en ese siglo y aun en el anterior llevan por título el de "Danza", "Baile", "Representación", "Juego", "Coplas" u otros por el estilo.

"Rorr. Hisp., II, 98.

7 Ibid., p. 374.

I Ibid., p, 374. 


\section{LAS DANZAS CON CANCION NARRATIVA EN LA ANTIGUUEDAD}

Esos raros arcaísmos de que habla Menéndez Pidal perviven, al parecer hasta hoy o hasta fechas muy recientes, en las apartadas islas Feröe, en donde se ejecutaba una danza coral al son de antiguas baladas de Sigurd o de modernos cantos de asunto local sobre alguna desgracia de pescadores, ${ }^{9}$ y en algunos otros lugares de los más recónditos de España. Y siendo España el país del romancero, es decir, de los cantos épico-líricos nacidos en la Edad Media y llegados hasta hoy por vía de la transmisión oral, es lógico que sean precisamente los romances los textos narrativos utilizados en las danzas cantadas.

Pero si en verdad esa modalidad de danza es hoy costumbre rarísima en España, no lo debió ser tanto en siglos pasados, a contar por la documentación y referencias que del tema nos han llegado. No ser tan raro como ahora no significa, sin embargo, que la danza cantada fuese la forma habitual del canto de los romances en los siglos XV, XVI y XVII. Los testimonios alegados por Menéndez Pidal, que es el único que ha iniciado el estudio de la cuestión, aunque no deba darse por agotada y merezca un estudio más detenido, ${ }^{10}$ hablan de una cierta popularización de esta modalidad de danza por algunas regiones de España; pero en absoluto puede deducirse que ésa fuese la única modalidad, y menos la más popular, y mucho menos que así fuese en toda España. Porque, en realidad, frente a la abundantisima documentación de textos romancísticos que, repartidos por pliegos y cancioneros, nos han dejado los siglos XVI y XVII, las otras noticias sobre su música, los instrumentos con que se acompañaban, los momentos en que se ejecutaban, si se bailaba o no con ellos, son extremadamente escuetas.

El baile se menciona en varias obras literarias, históricas o simplemente cronísticas, pero siempre de forma indirecta y de pasada. Lo que se deduce de esas escuetas referencias se resume en lo siguiente:

a) Que era costumbre propia de gente rústica y labradora, aunque lo más probable es que esa costumbre popular derivase de otra caballeresca medieval."

9 Ibid., p. 374.

10 Existe un estudio de las Danzas cantadas en el Renacimiento español de J. J. ReY (Madrid, SEM, 1978), pero en él no se menciona ni una sola romancesca y no, desde luego, porque no las hubiese.

"Cit. por Juan DE MENA en Las Trescientas, por G. Fernández de Oviedo en su Historia General de Las Indias (1547), y por J. SANCHEZ VAldes de la Plata en su Historia General del hombre (1598). Cf. Menéndez Pidal, Rom. Hisp. II, p. 99. 


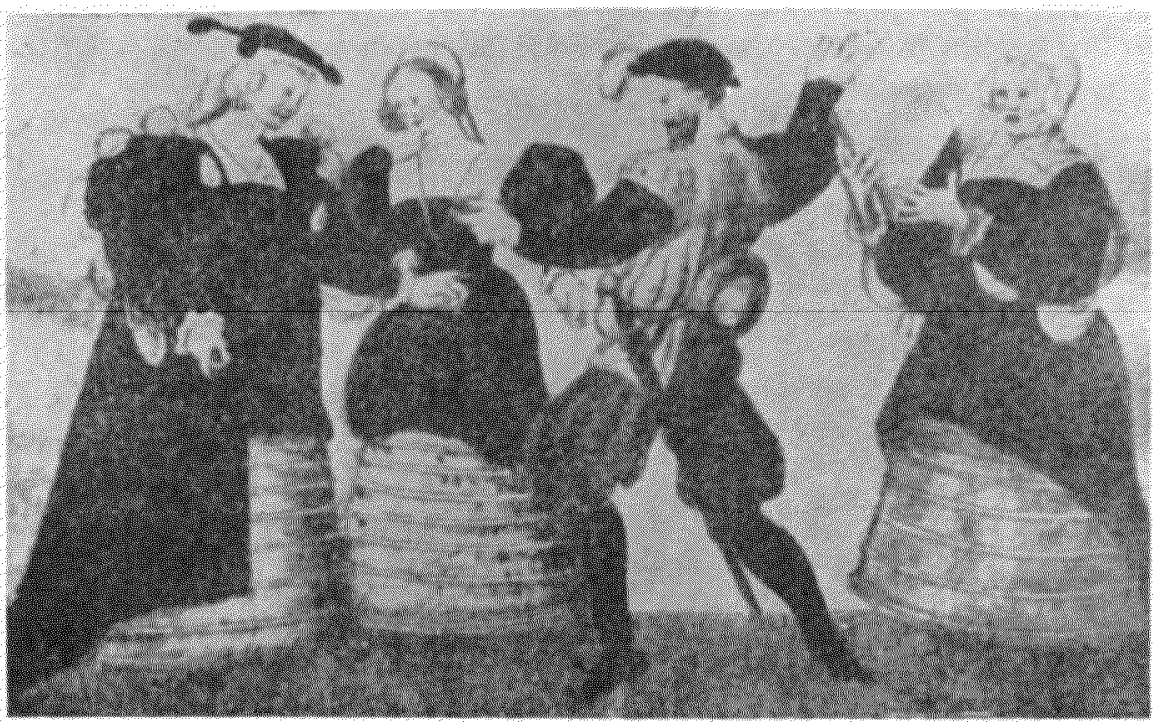

Fo. 1. Un balle rowancesco antwho Reconstruccion de un balle aristocratico de tres. acompanado de pandero cuadrado y de cantos de romances. Fotografia tomada de Menender Pidal, Esudios sobre el Rowancero, Madrid, 1973)

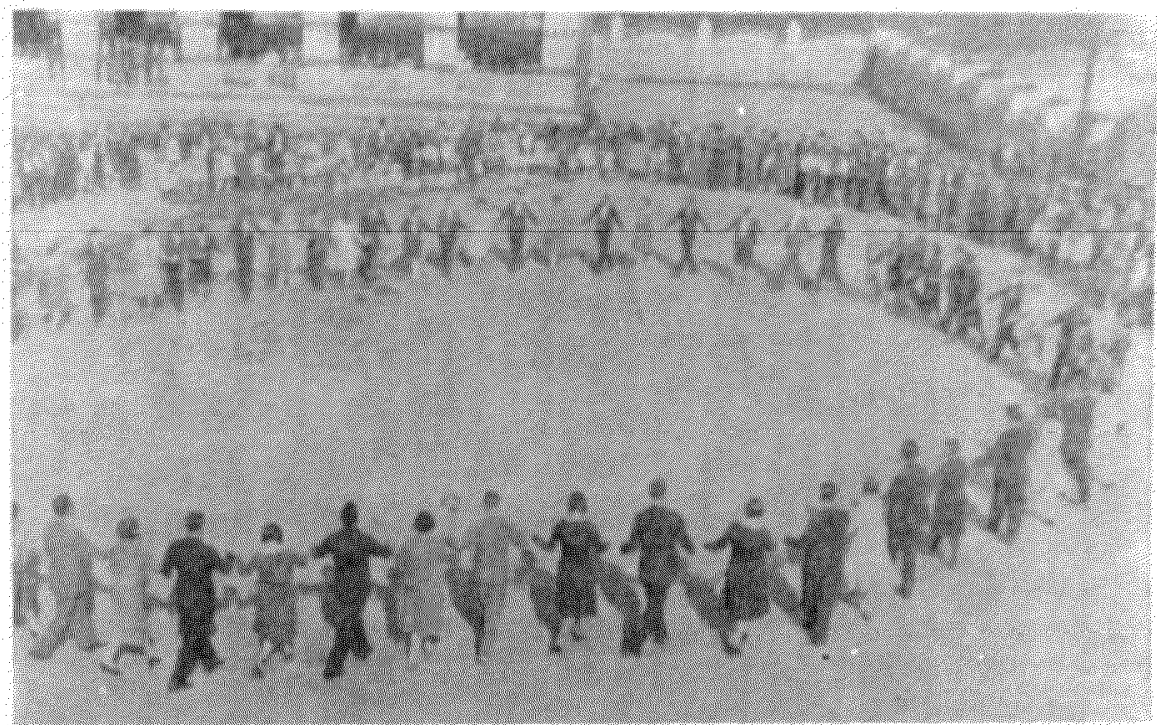

Fo. 2. La donza prima asturiana ballada en Mieres en 1930 en honor de Don Ramón Menendez Pidal, cartando el tradiconal romance paralelistico $\mathrm{A}$ y, wh rulón de esta villa! (Fotografla tomada de bidi) 
b) Que las danzas romancescas eran conocidas, por lo menos, en toda Castilla la Vieja, en tierras de Salamanca y de León ${ }^{12}$ y en las Asturias de Santillana. ${ }^{13}$

c) Que los instrumentos característicos utilizados en la danza eran las castañuelas y el pandero, ${ }^{14}$ que son instrumentos, junto con el tambor, típicos del folklore más arcaico.

d) Que sólo algunos romances específicos -y no cualquiera- eran propios para la danza, $15 \mathrm{y}$

e) Que la costumbre degeneró en jácaras o jacarandinas, avanzando el siglo XVII, como degradación del espíritu heroico que contenían los textos antiguos a otro burlesco y ahora rufianesco. ${ }^{16}$

\section{LOS BAILES ROMANCESCOS EN LA ACTUALIDAD}

El primero en conocerse en tiempos modernos y el más famoso de todos es la danza prima asturiana. Fue Jovellanos quien lo dio a conocer a finales del XVIII en una ya célebre carta sobre las romerias de Asturias. Y después, bien divulgando la noticia de Jovellanos, bien aportando nuevos datos desde un conocimiento directo de la realidad, otros escritores e investigadores ilustres, el Marqués de Pidal, Menéndez y Pelayo, Menéndez Pidal, Torner y muchos más, han escrito de manera que hoy la danza prima y el famoso romance que con ella se canta, el Ay un galán de esta villa, cuentan con una bibliografía de lujo, absolutamente desproporcionada con la que se ha ocupado de las otras danzas romancescas. El vacío bibliográfico sobre el resto hasta el siglo XX sería total si descartásemos la alusión que Estébanez Calderón hace en una de sus Escenas Andaluzas (1847) de "Un baile de Triana" en el que se cantan corridos (nombre que en Andalucía se da a

12 Cit. por J. Sanchez Valdes de la Plata. Cf. M. Pidal, Ibid., p. 99, nota 60.

13 Cit. por F. Sota en su Chronica de los Principes de Asturias y Cantabria (1681). Cf. M. PIDAL, Ibid., p. 99, nota 61.

14 Cf. M. Pidal, Ibid., p. 100.

15 Entre los citados expresamente Juan de Mena menciona uno sobre la muerte del rey Fernando el Emplazado; El Conde preso se bailaba en Asturias de Santillana; el de Morir se quiere Alexandre se cita en una composición del vihuelista Mudarra; el de Conde Claros es el más citado y debia ser el preferido para la danza; un romancillo hexasilábico sobre Santa Ana sirve para la danza cantada de Preciosa en La Gitanilla de Cervantes; otro sobre El caballero de Olmedo sirvió a Lope para su famosa obra del mismo título; y otros varios de tipo religioso se mencionan como "bailes a lo divino". Cl. M. PIDAL, Ibid., pp. 98-101 y 199-202.

16 Como el escarrián, que popularizó Quevedo. Cf. M. PIDAL, Ibid., pp. 199-202. 


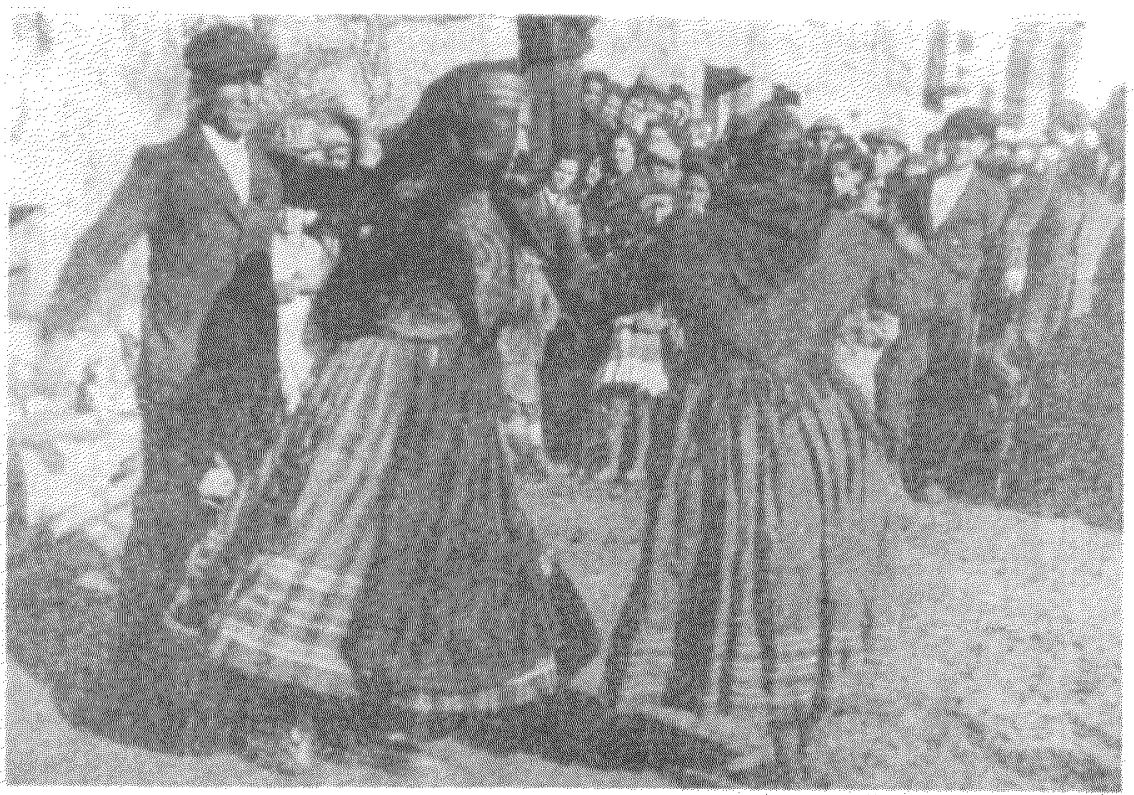

Fo. 3. El bahle de trex de Las Navas del Marqués (Avila) en 1930, al won de gutarras y el ronance de cerneldo. (Fotografia womada de bud?

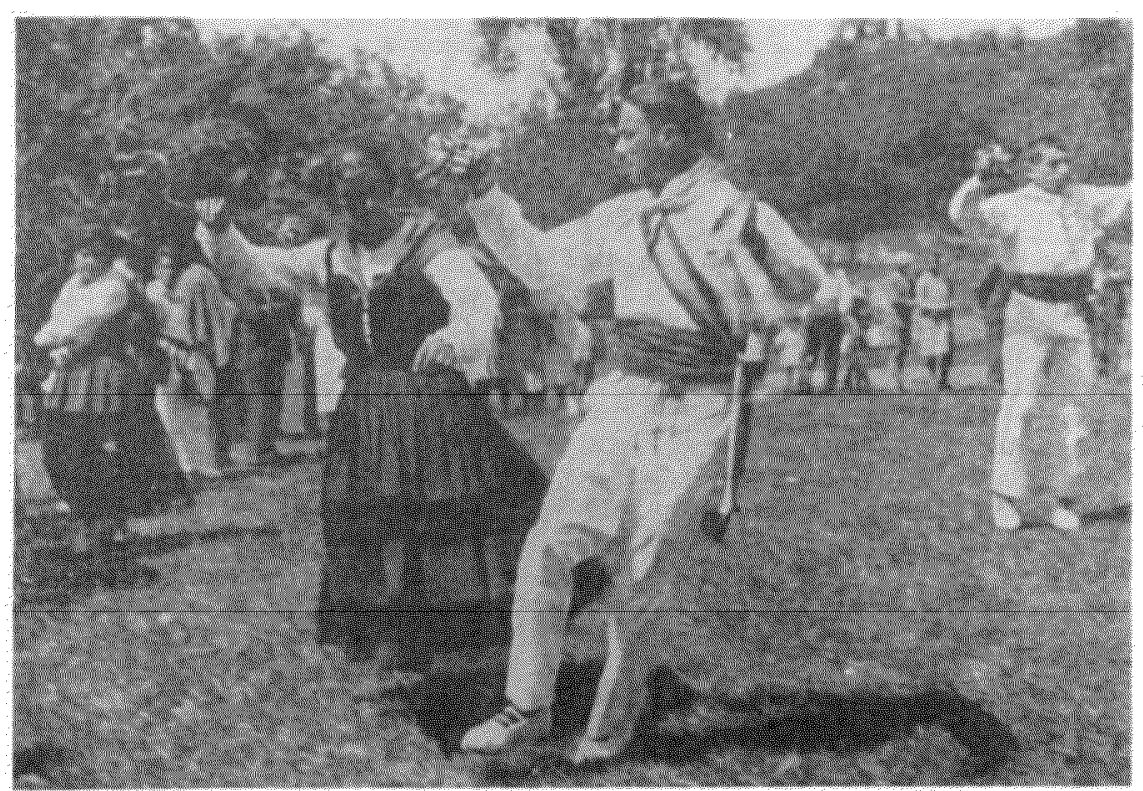

Fo. 4. El bahle a lo llano de Ruiloba (Sartander) con el que se solia cantar el womance de La condesta. (Fotografia tomada de bid) 
los romances cantados para diferenciarlos de otros géneros musicales) con romances tales como La Condesita, Gerineldo y otros. ${ }^{17}$

El descubrimiento de nuevos bailes romancescos en el primer tercio del siglo $\mathrm{XX}$ coincidió, y fue consecuencia de ella, con la intensa exploración del romancero por tierras españolas, realizada directamente unas veces por el matrimonio Menéndez Pidal y alentada otras veces sobre sus colaboradores. Así se "descubrió" el baile de tres de Las Navas del Marqués (Ávila), se constató la pervivencia de la danza prima en las zonas este y centro de Asturias (Llanes, Aller, Mieres y Candás como principales localidades) y se conocieron otros bailes antes absolutamente ignorados: el baile a lo llano de Ruiloba (Santander), el corri-corri de Arenas de Cabrales (Asturias) y el pericote de Llanes (Asturias). Eso por lo que respecta a la Peninsula. De Canarias, territorio tan alejado de la metrópoli y, por archipiélago, tan propicio para la conservación de arcaísmos, José Pérez Vidal dio a conocer en 1948 otro baile romancesco conservado en la isla de La Palma con el nombre de jila-jila o baile de las castañuelas. ${ }^{18}$ Pero antes, a finales del siglo XVIII, al tiempo que Jovellanos con la danza prima, algunos viajeros que llegaron a Canarias describieron otros bailes que, según todos los indicios, también eran romancescos. Así José Antonio de Urtusáustegui, que en 1785 viajó a la isla del Hierro y en el pago de El Pinar fue recibido con una especie de contradanza que allí llamaban baile de tres y en la que se cantaban "endechas y corridos" (es decir, como en Andalucía, romances). ${ }^{19}$ Así B. Carballo Wangüemert, que en 1862, como consecuencia de un viaje a la isla de La Palma, describe un baile de Santo Domingo en el cual -dice- se cantaban romances de

17 Cf. M. PIDAl, Ibid., p. 379. "En Andalucía -dice Durán-, con el nombre de corrio o carrido o correrilla llama la gente del campo a los romances que conserva por tradición" (A. Durán, Romancero General, I, Madrid, B.A.E., X, 1945, p. 177). Pero el nombre de corrido aplicado a los romances no sólo se da en Andalucía, se usa también en Chile (Cf. M. PIDAL, Los romances de América y otros estudios, Madrid, Espasa Calpe, Col. Austral, 7.a ed., 1972, p. 22) y se usó también en Canarias, como luego veremos.

$18 \mathrm{~J}$. PÉREZ VIDAL, "Romances con estribillo y bailes romancescos", en RDTP. IV (Madrid, 1948), pp. 197-241, reeditado con importantes ampliaciones en El Museo Canario (Las Palmas, 1949), pp. 1-58, y recogido en su libro Poesia Tradicional Canaria (Las Palmas, Excmo. Cabildo Insular de G. C., 1968), pp. 11-75, por donde citamos.

19 "La noche del día 11 -dice Urtusáustegui- la pasé en la casa del sargento, y aquella pobre gente para manifestar su regocijo, me obsequiaron con una huelga de bailes a su modo, que desempeñan con mucha agilidad, así hombres como mujeres, especialmente una especie de contradanza muy bonita, que llaman cruzar o el baile de los tres, compuesto de un hombre que ha de ser robusto y ligero, y de tres mujeres, muchachas y ágiles, al son de cierto guinso o tambor y flauta, cantando en este ínterin endechas o corridos con mucha gracia y expedición, aunque en tono melancólico: esta danza es peculiar de esta isla y consta de varias figuras". Cf. ahora J. A. de URTUSAUSTEGUI, Diario de viaje a la isla de El Hierro en 1779 , ed. de M. J. Lorenzo Perera, La Laguna, Centro de Estudios Africanos, 1983, p. 42. 
asunto guanchesco (es decir, de asunto y personajes canarios anteriores a la conquista de las islas). Este mismo baile de Santo Domingo y en la misma isla de La Palma será citado años más tarde, en 1900, por otro viajero, C. de Arribas y Sánchez, quien, sin embargo, dice -más acertadamente- que los romances que se cantaban eran "de los populares en España, de Carlomagno, los doce pares de Francia, hechos heroicos de bandidos", etc. ${ }^{20}$

Por muy poco que parezca, esto es todo lo que pervivía (o había llegado a conocimiento de la crítica) de un supuesto panorama anterior mucho más rico y variado. Pervivía decimos, porque ya ni siquiera todos ellos viven hoy. Una exploración actual de la tradición da como resultado inequívoco la decadencia más absoluta cuando no el olvido total. Por ejemplo, en pueblos de La Maragatería (León), informantes de romances actuales nos aseguraban la existencia de un baile que practicaban al son de la pandereta y el canto de romances como el de El bonetero de la trapería o La apuesta ganada. Por otra parte, José Manuel Fraile Gil, gran conocedor de la tradición oral y de los instrumentos musicales populares, ha recopilado en una amplia zona astur-leonesa (Tineo, Cangas del Narcea, Puerto de Leitariegos, Valle de Laciana) un baile que hoy se sustenta en el canto de coplas y el pandero cuadrado, pero que en otro tiempo no muy lejano fue sin duda romancesco, el son d'arriba. Este mismo baile debe ser el que menciona el erudito sueco Ake W. Munthe, como canto de romances y baile, al son de castañuelas y panderos cuadrados, en su recolección romancística de 1888 por las cercanías de Cangas de Tineo (Asturias). ${ }^{21} \mathrm{Y}$ debemos a este mismo amigo, José Manuel Fraile, la noticia de otro baile romancesco desconocido hasta ahora y todavía vivo, la charrada de Peñaparda (Salamanca), del que hablaremos en su lugar.

De todos ellos, el que parece más pujante es la danza prima, pero más por apoyos externos y "oficializados" que por dinámica propia. Hoy la danza prima se ha generalizado a toda la provincia y es conocida por todos los asturianos que han hecho de ella un verdadero símbolo de la región y canto nacional, de tal forma que no hay romería o fiesta local o conmemoración que no tenga como número final el baile de la danza prima. ${ }^{22}$

${ }^{20}$ Cf. Diego CATAlán en su introducción a La flor de la marañuela, I, Madrid, S.M.P.-Gredos (2 vols.), 1969, pp. 3-5.

${ }_{21}$ Cit. por Menendez Pidal, Rom. Hisp., II, pp. 285 y 377.

${ }^{22}$ Con todo, muchos se quejan que es más famosa que conocida. Menéndez Pidal afirma que siendo él asturiano no había tenido ocasión de ver la danza prima hasta 1930 en que el Orfeón Mierense organizó una fiesta en su honor. Vid. su "Ay un galán de esta villa", en De primitiva lirica española y antigua épica, Madrid, Col. Austral, 2." ed., 1968, pp. 123.128. 
El baile de tres de Las Navas del Marqués lo presenció Menéndez Pidal por vez primera en 1905 . En 1930 vuelve a presenciarlo, pero ya las cosas han cambiado mucho: ya nadie recuerda el romance de Gerineldo que antes era el canto predilecto para el baile, e incluso el mismo baile está en plena decadencia cuando "antes -dice- era cosa de todos los domingos". Diego Catalán volvió a Las Navas en 1970 y aunque no vio bailar pudo recoger una versión del Gerineldo de una mujer que había ido a bailar el baile de tres a Ávila hacia 1950. Es decir, ya recuerdo. Por último, en ficha de la Sección Femenina del Movimiento, revitalizadora de muchas costumbres locales durante el régimen de Franco, se dice que el baile de tres fue bailado en un Concurso de la propia Sección Femenina -y por tanto por un grupo de jóvenes previamente ensayados y no necesariamente de Las Navas del Marqués- en 1954, no se dice dónde. ${ }^{23}$ Es decir, ya archivo. Ahora que Las Navas está semidespoblado y que la Sección Femenina desapareció por completo, ya ni recuerdo ni archivo.

El baile a lo llano de Ruiloba (Santander) fue también presenciado por Menéndez Pidal en 1930, pero nada nos dice de la frecuencia y de la vitalidad de la tradición. Detrás de él, la Revista Estampa ( 9 de septiembre de 1930) publicó un reportaje del baile con descripción de la danza, con muchos elogios sobre el romance de El Conde Sol (también llamado La boda estorbada o La Condesita) que se cantaba como propio del baile y con no pocas suposiciones sobre su origen y carácter. ${ }^{24} \mathrm{Y}$ después, aunque sólo de pasada y sin ningún dato novedoso, en 1948 vuelve a mencionarlo Sixto Córdoba y Oña en su Cancionero de Santander. ${ }^{25}$ Ninguna otra noticia tenemos del baile de Ruiloba desde entonces, así que no sabemos si vive aún o si queda ya como recuerdo local. ${ }^{26}$

El pericote es el baile típico de la localidad asturiana de Llanes. Antiguamente se bailaban con él romances religiosos y un romance

23 Vid. Menéndez Pidal, Romancero Tradicional, VIII (Gerineldo, III), Madrid, S.M.P. Gredos, 1976, pp. 357-365, en donde se recoge el original de campo (y su correspondiente transcripción) del propio don Ramón con notas referidas a la descripción del baile y a sus impresiones primeras, así como una fotografía del baile, la música del canto y unas notas añadidas de Diego Catalán.

${ }_{24}$ Igualmente se reproduce íntegro el reportaje de Estampa, la música del romance y otros datos del baile de Ruiloba en MEnéndez Pidal, Romancero Tradicional, IV (Temas Odiseicos, (I), Madrid, S.M.P.-Gredos, 1970, pp. 45-49.

25. $\mathrm{S}$. CÓRDOBA Y ONA, Cancionero popular de la provincia de Santander (5 vols.) Santander, 1948.

26 Desde luego ya ni es mencionado en las obras panorámicas actuales del folklore español, como ocurre, por ejemplo, en la de J. Crivillè y Bargallo, Historia de la música española, VII: El folklore musical, Madrid, Alianza, 1983, en donde, por el contrario, sí se mencionan otras varias danzas de Santander. 


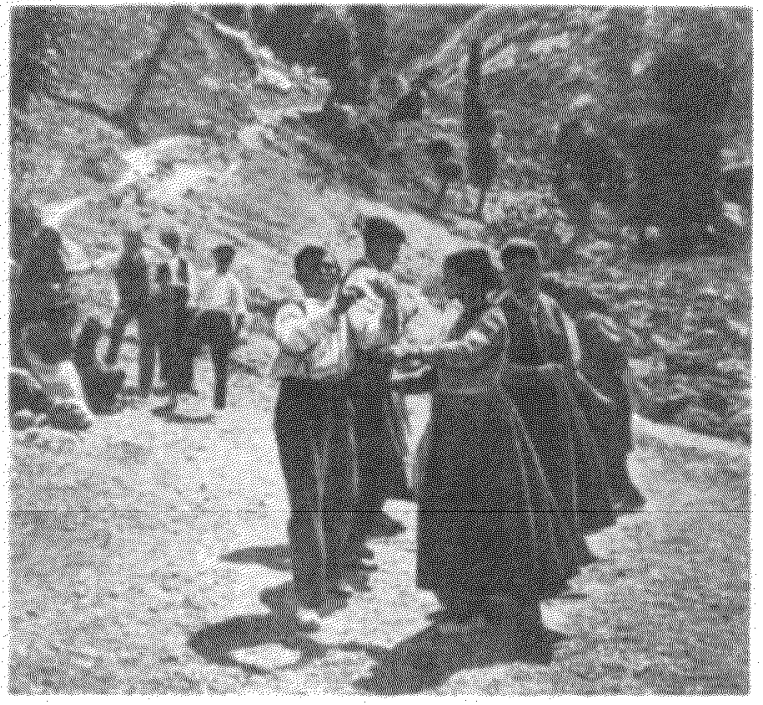

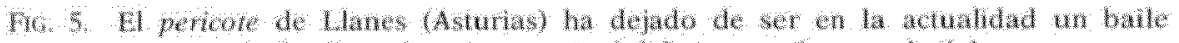
romancesco, pero lo fue hasta la primera mitad del $x$, con cl gue se balaba un romance muy peculia, if de Espuela, un dieciochesco de una bandolera westida de varón.

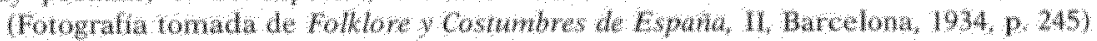

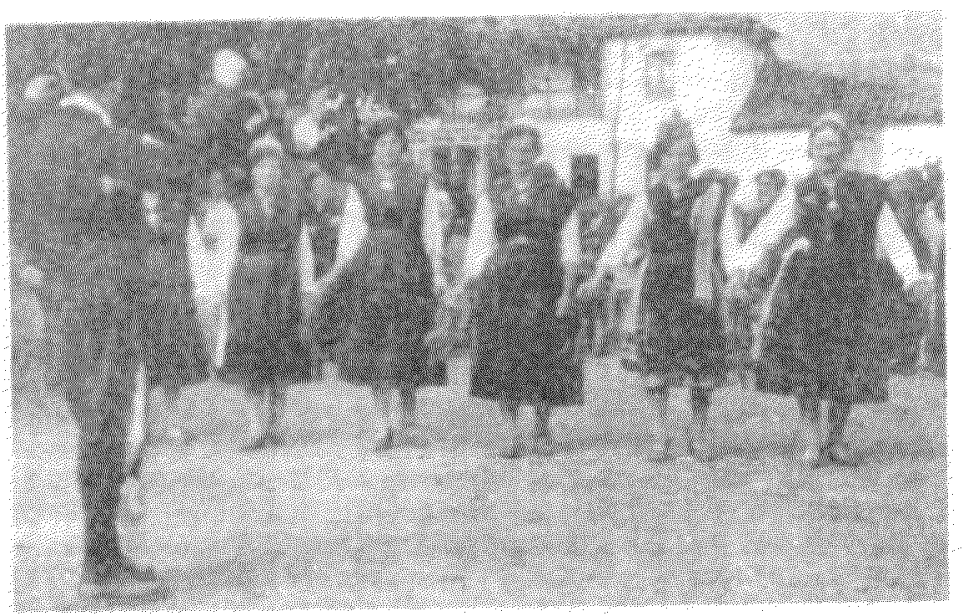

Fi. 6. El comicomi cra un balle tipico de Cabrales (Asturias) con el que se cantaban

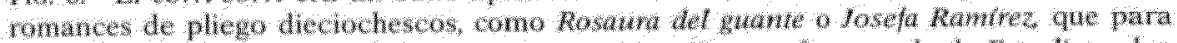

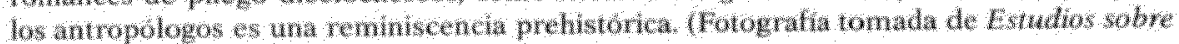
el Rowaneerol 
profano muy peculiar, el de Espinela, un romance de pliego del siglo XVIII en el que se cuenta la historia de una bandolera vestida de varón. ${ }^{27}$ Pero de aquello no queda nada. Ya cuando Menéndez Pidal lo presenció en 1930 "coplas y no romances" dice que oyó. ${ }^{28}$ Años antes, hacia 1920, Eduardo M. Torner recoge el baile en su extraordinario Cancionero ${ }^{29}$ pero nada nos dice de lo que en él se cantaba. Y años más tarde, en 1934, Aurelio Capmany, en su panorámica visión del folklore español, ${ }^{30}$ se limita a copiar como propio lo que había dicho antes Torner sin tan siquiera añadir una nota novedosa. Actualmente las coplas que en su día sustituyeron a los romances han venido a ser sustituidas, a su vez, "por el solo concurso de la gaita asturiana", 3 con lo que, de hecho, el pericote ha dejado de ser no ya una danza romancesca sino incluso una danza cantada. ${ }^{32}$

El corri-corri de Arenas de Cabrales (Asturias) es el paralelo del pericote de Llanes, con el que tiene muchas concomitancias, como las tienen también las comarcas en las que vive cada uno de ellos, justo en las dos vertientes de una misma montaña, hacia el mar la de Llanes y hacia los Picos de Europa la de Cabrales. Y paralela degradación progresiva ha sufrido el corri-corri como danza romancesca que fue en otros tiempos símbolo de todo un pasado. Menéndez Pidal, quien la presenció en 1930 (el año providencial para las danzas romancescas), dice que el canto de los romances tradicionales había sido sustituido por el de los dieciochescos (del tipo Rosaura la del guante, Doña Josefa Ramirez y otros así) y sobre todo por el de los romances religiosos. ${ }^{33}$

27 El romance lo hemos recogido nosotros, por primera vez en Canarias, precisamente en la isla de La Gomera, en Valle de Gran Rey, en donde, aunque a nosotros se nos trnsmitió recitado, se utiliza (o puede utilizarse) como canto del baile del tambor gomero.

28 Menendez Pidal, Rom. Hisp., II, p. 378.

29 Eduardo Martínez Torner, Cancionero Musical de la Lírica Popular Asturiana, Madrid, 2." ed., 1971, núm. 86.

30 A. Capmany, "El baile y la danza", en F. Carrera y Cand, Folklore y Costumbres de España, II, Barcelona, 1934, p. 244.

3) J. CRIVIllè Y Bargalló, cit., p. 233.

32 Durante el auge de los Coros y Danzas de la Sección Femenina, un grupo de danzas asturianas, el de Gijón, tenia entre su repertorio el baile del pericote, pero, por lo que nos dicen, en él se tocaba la gaita y el tamboril y nunca se llegaron a cantar romances, $n$ siquiera coplas. Esta es la misma impresión que da José Benito A. BuYLLA, al hablar por extenso del pericote en su libro La canción asturiana (Oviedo, Col. Popular Asturiana, 1977), que es el estudio más moderno que conocemos. Efectivamente el baile pervive, pues habla de que en 1975 se anunciaba entre los actos del programa de un festival folklórico de Llanes, pero añade más adelante que "actualmente se baila muchas veces al compás de gaita y tambor, innovación poco acertada que apenas añade color a la danza y desde luego le resta carácter y autenticidad" (p. 98). Por lo demás, Buylla nunca menciona el canto ni los textos en el pericote.

33 Vid. Menendez Pidal, Rom. Hisp., pp. 377-378. 
Los demás autores que han hablado del corri-corri (en realidad los mismos que sobre el pericote) nunca han mencionado su carácter romancesco. Torner acompaña la música que recogió en 1920 con la letra de una copla que nada tiene de romancesca:

$$
\begin{aligned}
& \text { Fuime a la mar y pesqué } \\
& \text { un pescadito en la rede, } \\
& \text { un pescadito en la rede; } \\
& \text { iay! quién te pescara a ti, } \\
& \text { niña de la saya verde. }{ }^{34}
\end{aligned}
$$

Las noticias más recientes hablan de la decadencia del baile $y$, desde luego, del olvido total de los romances. ${ }^{35}$

En Peñaparda, en la comarca de El Rebollar, al sur de la provincia de Salamanca, se conserva aún vivo otro baile romancesco que allí llaman la charrada. El nombre no es exclusivo del baile de Peñaparda, al contrario, es común por amplias zonas de Salamanca en donde charro es gentilicio y en donde la charrada es ritmo y baile típico. Pero sólo en Peñaparda el baile se asocia al canto de los romances. Decimos que sigue vivo, pero cada vez menos porque allí también las coplas sustituyen por lo normal al canto narrativo: sólo los más viejos prefieren éstos a aquéllas. El instrumento típico del baile es el pandero cuadrado, que a veces tocan con una baqueta para marcar mejor su vivísimo ritmo. Lo toca una sola mujer, la "panderera", que es a la vez la cantadora del romance. A veces la panderera es sustituida por el "tamboritero", quien con su tambor y flauta evita el canto. El cuerpo de baile lo forman mujeres y hombres, sin límite en el número, en filas enfrentadas. El baile tiene cuatro partes bien diferenciadas por su ritmo: el ajechao, el sorteao, el corrido y el picao. A lo que parece, sólo en las dos primeras se cantan romances tradicionales, siendo propios de la primera El Conde Niño y La malcasada, y de la segunda La apuesta ganada y Don Gato. En las otras dos partes o se cantan coplas o se baila sin cántico. ${ }^{36}$

34 TORner, Cancionero, n." 144.

35 El corri-corri fue también un baile que tomó entre los de su repertorio el grupo folklórico de la Sección Fernenina de Gijón, pero sin el canto de los romances. Por noticias que nos proporciona Buylla, el corri-corri se bailó en las fiestas de San Roque de Llanes en 1975 (debe ser la misma fiesta mencionada antes para el pericote), aunque nada se diga de si por los propios habitantes de Arenas de Cabrales o por un grupo folklórico cualquiera (Vid. J. B. A. BuYLLA, La canción asturiana, pp. 83-91).

${ }^{36}$ Debemos la noticia y la descripción del baile a nuestro amigo José Manuel Fraile Gil. Recientísimamente se ha editado un disco que contiene estos bailes y algunos comentarios pertinentes: Cancionero Tradicional del Campo de Ciudad Rodrigo (vol. 2): El Rebollar, Madrid, Tecnosaga, S. A. VPD-1064. 
De los bailes de corridos que Estébanez Calderón describió en Andalucía a mitad del siglo pasado, ninguna noticia queda en la actualidad. Y de Canarias, región que junto a la asturiana se muestra la más conservadora en estos raros arcaísmos, lo que queda es lo siguiente. El baile que José Antonio Urtusáustegui presenció en 1785 en Hierro ha desparecido por completo y no queda en la isla ningún baile que pueda ser llamado romancesco. ${ }^{37}$ Cuando nosotros mismos recorrimos la isla toda en 1982 haciendo encuestas romancísticas, preguntamos insistentemente a los más viejos si en alguna ocasión los romances se habian bailado, y las contestaciones eran contradictorias: unos que no, que nunca, y otros que sí, que eso era lo que habian oído decir a sus antepasados. En fin, noticias que, en todo caso, constataban no ya la pérdida del baile en conexión con los romances, sino incluso el recuerdo de este fenómeno. El nombre que le daban los últimos era el de la meda, que es justamente el nombre que pervive hoy en la isla para denominar el canto de los romances que, eso sí, en El Hierro siguen cantándose todos con una misma melodía y con el acompañamiento de un gran tambor. ${ }^{38}$

El otro baile del que tenemos noticia por los viajeros del XIX a la isla de La Palma, el del Santo Domingo, citado por Carballo Wangüerment (1862) y por C. de Arribas y Sánchez (1900) y descrito por el primero, creemos que no es otro que el denominado por Pérez Vidal baile del jila-jila o de las castañuelas. En cuanto a su pervivencia, ya de Arribas y Sánchez advertia en 1900 que "va perdiendose la costumbre del baile y quedando en cambio el canto o cantiga, como dicen los naturales". ${ }^{39}$ Y Pérez Vidal en 1948 confirma tajantemente que "ya no se practica en la isla de La Palma, donde, en algunas localidades, fue

"Eso es lo que se desprende también del estudio de S. Jimenez SANChez, "Danzas y canciones de la isla del Hierro", en RDTP, III (Madrid, 1947), pp. 303-315. Lothar Siemens, sin embargo, dice que el actual tango herreño que se baila en la isla puede acaso identificarse con el baile de tres de que hablaba Urtusáustegui (Cf. Lothar SiEmens, La Muisica en Canarias, Las Palmas, El Museo Canario, 2." ed., 1984, p. 47), aunque los textos que hoy se cantan no son romancescos.

${ }^{38}$ El resultado de aquellas encuestas y una visión más pormenorizada de estos temas puede verse en nuestro Romancero de la isla del Hierro (con la colaboración de Helena Hernández Casañas y un estudio de la música por Lothar Siemens Hernández), Madrid, S.M.P.-Gredos, con la colaboración del Cabildo Insular del Hierro, 1985.

39 "Das o tres hombres tocan el tamboril con el acompañamiento de alguna pandereta. El principal canta un romance, y sus compañeros cantadores repiten a cada estrofa o cuarteta una tonadilla..." (Cit. por D. CATALAN, La flor de la marañuela, I, p. 4). Es decir, exactamente igual que ahora se cantan los romances en las islas más occidentales de Canarias. 
casi exclusivo hasta hace unos treinta años". ${ }^{40}$ En la actualidad, según noticias de nuestro amigo palmero Talio Noda, quien ha rastreado minuciosamente la isla en busca de cualquier manifestación folklórica, ya no se baila en ningún lugar y, a lo más, lo que queda es una débil memoria en los más viejos de los pueblos en los que antes era cotidiano.

\section{EL BAILE DEL TAMBOR DE LA GOMERA}

Frente a este panorama de ruinas, el baile del tambor de La Gomera se alza como el último testimonio de una cultura secular. Cuando por todas partes no hay sino abandono y olvido, en la isla colombina, sin duda por el aislamiento tremendo en que ha vivido desde siempre, siguen cantando y bailando los romances con tal pujanza y con tanta asiduidad como si en el siglo XV o XVI vivieran. No hay reunión, fiesta, romería o regocijo popular cualquiera que no acabe en baile del tambor, no hay gomero o gornera que no sepa bailar su baile del tambor y no hay pueblo en la isla que no disponga de uno o de varios alamados cantadores que a su alrededor convoquen a todo el pueblo para cantar y bailar. El baile del tambor es, sin más, el baile de La Gomera. Pero no sólo en el sentido de que se baile en La Gomera, sino en el más estricto de que no hay otra manifestación popular en la isla -ni danza, ni canto, ni música- que pueda comparársele. Existe, sí, otra danza que se llama Santo Dontingo, pero que ni con mucho alcanza en popularidad y frecuencia a la del tambor. Además, en el Santo Domingo no se utiliza la canción narrativa -los romances- sino dísticos decasilabos que invocan al santo de quien recibe el nombre, que hablan de asuntos locales y que se alargan o se acortan en el canto a voluntad del cantador. Coplas de este estilo:

Santo Domingo de la Calzada llévame a misa de madrugada.

Santo Domingo, Domingo santo, sobre mi capa tiende tu manto.

th Tal variedad de nombres responde, según las localidades de la isla, a alguno de us las danza asi de las jilanderas, del jita-jila o baile jilado por la imitación que las mujeres hacen mientras bailan a la tarea de hilar, ast en Bartovento el de zapateado por los violentos zapateados que hacen los hornbres al bailat Bef parion (CE. Perge VIDal, Poesia tradicional canaria, precuente en los estribillos (o tonadilla o resprander) del corro. 
Hice un viajecillo pa La Gomera en busca de alguien que me quisiera.

Con miel de palma y gofio en polvo en Tamargada besé a mi novio.

El baile del tambor se denomina a veces también tajaraste gomero, y otras veces baile de procesión, pero el nombre primero, o simplemente tambor, es el más genérico y popular. ${ }^{41}$

\section{ANTECEDENTES BIBLIOGRÁFICOS SOBRE EL BAILE DEL TAMBOR}

Contando, pues, con caracteristicas tan sobresalientes, asombra el silencio tan prolongado en que ha vivido este baile romancesco de $\mathrm{La}$ Gomera. Se conocía, sí, a nivel local y regional, pero sólo como danza típica, sin más. ${ }^{42}$ Por desgracia no llegó a La Gomera ninguno de aquellos viajeros de los siglos XVIII y XIX que dejaron por escrito sus noticias e impresiones sobre otras islas del Archipiélago Canario y que tanto valor tienen para nosotros ahora. La Gomera ha estado casi siempre al margen de toda ruta viajera, olvidada a su propia suerte. Desde luego la noticia sobre el baile del tambor faltaba en los estudios sobre el romancero, pero es que faltaba incluso la noticia sobre el propio romancero de La Gomera, cuando ahora se nos ha mostrado como el territorio más importante que queda hoy en el mundo hispánico en la conservación del romancero tradicional. Un ejemplo: Desde 1969, en que se publicó La flor de la marañuela como romancero general de las Islas Canarias, se conocían 26 versiones de 19 romances gomeros. En las encuestas que nosotros realizamos en la isla en el

41 Con el nombre de tajaraste existe otra danza en Tenerife que poco o nada tiene que ver con el baile de La Gomera. Y además, con el nombre de tajaraste gomero se ha difundido por discos y actuaciones de grupos folklóricos "urbanos" del resto de las islas - desde Los Sabandeños hasta Los Gofiones, pasando por Los Huaracheros y Sirinoqueotro género de canto (no sé si tambièn de baile pues estos grupos no tienen cuerpo de bajle) bien distinto al baile del tambor. Se trata de una sucesión de estribillos (pies de romances de los utilizados en el baile del tambor) que, como en el Santo Domingo, pueden alargarse o acortarse: "Quitate de alante, Arure, / que quiero ver a Chipude", "Hice una raya en la arena / por ver el agua donde llega", "El gomero que no canta / penas tiene que no aguanta", etc. La alternancia de solo y coro en el canto es igual a la del tambor, pero la música y el ritmo son muy distintos $y$, sobre todo, nada tiene este "tajaraste" de canto narrativo romancesco.

${ }^{42}$ En realidad eso mismo ha ocurrido y ocurre con el resto de las danzas romancescas dentro de los ámbitos geográficos en los que viven. Su carácter de danza con canto narrativo ha pasado desapercibido a cuantos se han acercado a ellas; y como éstos han sido, por lo general, aficionados al folklore se han fijado en la música, en la coreografía, en los instrumentos, etc., pero no en el texto que sirve para el canto. 
verano de 1983 logramos una colección de 402 versiones correspondientes a 144 temas romancísticos. Y al margen la cantidad, La Gomera tiene entre su repertorio alguno de los temas más raros y apreciados del romancero tradicional moderno, como El Cid pide parias al rey moro, Río Verde, Lanzarote y el ciervo del pie blanco o Paris y Helena.

Desde luego, Menéndez Pidal no llegó a tener noticia del baile de La Gomera, pues ni lo cita entre los bailes romancescos que aún quedaban en España a la hora de publicar en 1953 su magistral Romancero Hispánico. Pero tampoco Pérez Vidal, lo que es mucho más raro, siendo como es él canario de nacimiento y habiéndose dedicado durante muchos años al estudio del romancero canario, entre cuyos trabajos hay uno justamente con el título de Romances con estribillo y bailes romancescos. ${ }^{43} \mathrm{Y}$ es que Pérez Vidal en sus investigaciones de campo no salió de su isla, La Palma, y a ella ciñó sus estudios. ${ }^{44}$ Otros estudiosos sí han hablado del baile del tambor, pero sólo desde el punto de vista de la danza. Así Lothar Siemens, que es quien más y mejor conoce las tradiciones musicales canarias, en un breve y compilador estudio dice: "En La Gomera hay que destacar una peculiar agrupación tradicional en el acompañamiento de su típico baile del tambor, danza de marcadas concomitancias astúricas: el tambor de cilindro corto y unas enormes y barrigudas castañuelas, que son repiqueteadas enérgicamente por hombres danzantes". ${ }^{45}$ Y más adelante: "Otro baile de filas enfrentadas de hombres y mujeres que ha llegado con gran pujanza hasta nuestros días en la isla de La Gomera es el baile del tambor, llamado también tajaraste gomero". ${ }^{46}$ Estas originales apreciaciones de Siemens nos servirán más adelante para nuestras argumentaciones, pero por ahora interesa señalar la ausencia de todo comentario a los textos que hacen del baile del tambor una danza cantada y romancesca. Así Crivillé: "Las islas de Hierro y de La Gomcra, por su aislamiento prolongado, parecen haber sido las que más y mejor han conservado aquel particular primitivismo y ancestral resabio en su música tradicional... La isla de La Gomera guarda precisamente un tipo de baile de original textura: es El baile del

43 Cf. Perez Vidal, Poesia tradicional canaria, cil., pp. 11-75.

44 A La Palma ciñó sus estudios y sin embargo la critica posterior ha generalizado a todas las Canarias -quizás por el título que el propio autor utilizó: "El estribillo en el romancero tradicional canario"- lo que es exclusivo de La Palma (o de algunas islas), es decir, la práctica de los estribillos o responderes en el canto de los romances. Cf. nuestro Romancero de Gran Canaria, I, Las Palmas, 1982, pp. 47-49.

45 L. Siemens, La música en Canarias, cit., p. 35.

46 Ibid., p. 49. 
tambor". ${ }^{47}$ Así Talio Noda en un opúsculo sobre la música tradicional canaria en donde se describe el baile del tambor, pero sin mencionar para nada el canto de los romances, y eso que en páginas anteriores habla de los romances tradicionales como género folklórico canario importante. ${ }^{48}$ Así, en fin, Elfidio Alonso en su antología Tierra Canaria, en donde estudia con cierto detenimiento los elementos componentes del baile gomero (las chácaras, el tambor, el baile, el silbo), pero confundiendo totalmente el carácter de los textos que se cantan. "El cuarto elemento -dice E. Alonso- es el guineo o canto del solista, que entona un pie de romance que luego corean bailarines, tocadores y danzantes. Los pareados abordan los más variados temas, desde lo religioso hasta las rencillas entre los pueblos, pasando por sentencias y antiguos refranes". Y da un poco más abajo una muy equivocada visión de los responderes. "En los pareados fijos y más usuales -sigue diciendo E. Alonso- encontramos, a veces, valiosos textos del romancero". Y cita como ejemplo el de:

Vengan aires de mi tierra que los de aquí me dan pena.

que lo emparenta con la coplilla antigua recogida por Correas:
Aires de mi tierra
vení y llevadme,
que estoy en tierra ajena
no tengo a nadie.

sin tener en cuenta que esos versos pertenecen a la lírica popular y no al romancero, siendo como son géneros diferentes. ${ }^{49}$

Quien únicamente acierta a relacionar baile-canto de romances es Concepción González Casarrubios en un pequeño artículo aparecido en la Revista Narria, formando parte de un conjunto bastante amplio de trabajos destinados a la divulgación del folklore y de las tradiciones populares de España. ${ }^{50}$ Acierta plenamente al decir que los romances se utilizan para el baile del tambor en La Gomera y que se conservan gracias a esa función. Sin embargo, la exposición de González Casarru-

47 Criville y Bargalló, El folklore musical, p. 262.

48 Talio Noda, La música tradicional canaria, hoy, Las Palmas, 1978.

49 Elfidio Alonso, Tierra Canaria, Madrid, 1981, fasc. 5. s.p. En realidad este autor confunde el baile del tambor con ese otro baile gomero mencionado antes que los grupos folklóricos "urbanos" han confundido con el nombre de "tajaraste gomero".

so C. González CASARrubtos, "Instrumentos musicales, canciones y bailes de La Gomera, en Narria, n. ${ }^{\circ}$ 19, Universidad Autónoma de Madrid, 1980. 
bios puede dar lugar a confusiones respecto a los bailes gomeros. Digo "bailes" y no baile porque así se especifica en su artículo: Después de hablar del tambor-también llamado correctamente tajaraste-como el más generalizado y genuino de La Gomera menciona otros bailes: el cambio de mudanzas, el Santo Domingo y el baile de procesión. Pero en realidad en la Gomera hay sólo dos bailes: el baile del tambor (o tambor - tajaraste) y el Santo Domingo. Lo de cambio de mudanzas es una invención relativamente reciente del Grupo de Danzas de Hermigua y de su fundadora y directora Lydia Ascanio a quien se debe, por cierto, el poco o mucho conocimiento que del folklore gomero se tiene en otras islas del Archipiélago. ${ }^{51} \mathrm{Y}$ lo de baile de procesión-denominación que nosotros nunca oímos en la isla sino sólo a Lydia Ascanio, a quien tuvo González Casarrubios por informante- no es sino otra denominación del baile del tambor por bailarse también en las procesiones religiosas.

\section{DESCRIPCIÓN DE UNA FIESTA GOMERA}

Las oportunidades que al gomero se le presentan para cantar romances y bailar el baile del tambor son muchas, tantas como él quiera. En realidad basta un cantador, un grupo que responda, unos cuantos tambores y otros que quieran bailar y tocar las chácaras. Naturalmente, no todos son cantadores, es decir, solistas que sepan romances y sean capaces de entonarlos al ritmo de los instrumentos y del baile, pero sí que todos o la mayoría saben tocar el tambor y las chácaras y desde luego que todos saben bailar. La oportunidad puede presentarse en cualquier momento: una celebración familiar, una reunión de vecinos, un rato de divertimiento entre amigos. Y si no hay gente suficiente para el baile siempre es fácil al menos reunirse para el canto. Pcro cuando verdaderamente se muestra el baile del tambor en su plenitud es en las fiestas locales, cuando la romería y la celebración atraen a los de los pueblos vecinos y se forma entonces un "rancho" numeroso capaz de alternarse para que la fiesta no decaiga en toda la tarde, en toda la noche o en todo el día. Así que los gomeros,

si El Grupo de Hermigua se creó en 1954 como Grupo de la Sección Femenina y el cambio de mudanzas fue una "creación" a base de pasos y mudanzas recogidos por la isla que utilizaba el Grupo en sus actuaciones públicas como intermedio -como mudanzaentre romance y romance, o lo que es lo mismo, entre dos bailes de tambor. Pero no es baile tradicional en La Gomera. Sin embargo las actuaciones del Grupo de Hermigua por el resto de las Islas Canarias han tenido éxito y el cambio de mudanzas-aunque sin bailees lo que los demás grupos canarios han tratado de imitar con el equivocado nombre de tajaraste gomero del que antes hemos hablado. 
amantes de sus tradiciones, peregrinan de pueblo en pueblo en los días de sus fiestas patronales y tienen oportunidades de formar coro. No es necesario director alguno ni agrupación previamente ensayada. La espontaneidad y el saber heredado se juntan en la manifestación folklórica más auténtica y natural que pueda pensarse. Ni vestimenta especial, ni lugares previamente acondicionados, ni coreografías y grupos ensayados de antemano. La ropa: la de todos los días, el lugar: cualquiera y cuantos hombres y mujeres quieran sumarse a la fiesta bastan para el baile del tambor.

En este sentido, el baile de La Gomera se diferencia radicalmente de los otros bailes romancescos, pues éstos se ejecutan -o ejecutabansólo en fechas muy señaladas del año. Así, por ejemplo, el de Ruiloba el día de la Virgen de agosto, el de Arenas de Cabrales en las festividades de San Juan y San Pedro, el de Llanes en las de Santa María Magdalena, San Roque y en la de la Virgen de Guía, la danza prima en San Pedro, San Roque y la Magdalena y en otras romerías locales, y el jila-jila de La Palma en algunas fiestas como las de la Cruz. Sólo el baile de tres de Las Navas se bailaba todos los domingos y en las bodas, y la charrada de Peñaparda se baila en las fiestas domésticas y locales y en cualquier otro acontecimiento que lo merezca.

Las fiestas gomeras en las que suele organizarse los más celebrados bailes de tambor son las siguientes:

\begin{tabular}{lll}
\multicolumn{1}{c}{ Fecha } & \multicolumn{1}{c}{ Lugar } & \multicolumn{1}{c}{ Festividad } \\
1.er domingo de octubre & $\begin{array}{c}\text { Puntallana-San Sebas- } \\
\text { (cada } 5 \text { años) }\end{array}$ & Virgen de Guadalupe \\
6 de enero (Reyes) & Valle Gran Rey & Virgen de los Reyes \\
2 de febrero & Chipude & Virgen de Candelaria \\
15 de mayo & La Palmita & San Isidro \\
13 de junio & Valle Gran Rey & San Antonio \\
24 de junio & Valle Gran Rey & San Juan \\
29 de junio & Valle Gran Rey & San Pedro \\
16 de julio & Playa de Santiago & Virgen del Carmen \\
25 de julio & Playa de Santiago & Santiago \\
Último domingo de julio & El Cercado & Virgen del Pino \\
15 de agosto & Chipude & Virgen de Candelaria \\
16 de agosto & Arure & San Salvador \\
24 de agosto & Alojera & San Bartolomé \\
30 de agosto & Las Rosas & Santa Rosa de Lima \\
Ültimo domingo de agosto El Cedro & Virgen de Lourdes \\
8 de septiembre & Chipude & Virgen de Candelaria \\
15 de septiembre & Alajeró & Virgen del Paso
\end{tabular}

Nosotros asistimos a la de Santa Rosa de Lima, en el pueblo de Las Rosas (ayunt. de Agulo), los días 20 y 21 de agosto de 1983. Y esto es lo que vimos. 
Los altavoces con música moderna empezaron a sonar al atardecer del sábado $20 \mathrm{y}$ los bares y chiringuitos que rodeaban la plaza de la pequeña ermita del pueblo, lugar destinado para la fiesta, empezaron a funcionar desde que hubo gente que se acercase a ellos. Los tambores y las chácaras se retrasaron hasta la noche por no encontrar un lugar capaz de aislar la música ensordecedora de los altavoces. Al final, también dentro de la plaza, en un lateral de la ermita, en el lado opuesto de los altavoces, se congregó la fiesta de los viejos. La de los viejos, porque la de los jóvenes estaba al otro lado de la ermita, al lado de las guitarras eléctricas, de las baterías y de los altavoces. Los viejos, los del tambor, al principio solo cantan, pero luego, poco a poco, se van animando otros y van saliendo a bailar hasta formar un grupo mediano de bailadores, llegando en lo más alto de la fiesta hasta 6 ó 7 parejas. Los que cantan son más: no hay un número fijo, porque unos llegan y otros se van según avanza la noche, pero entre tocadores y cantadores llegan a 15. Un solista inicia un romance eligiendo primero un estribillo -el pie- que será lo que cante el coro a lo largo de todo el relato a cada dos versos octosílabos del solista:

Solista: Santa Rosa, madre mía, hoy se celebra tu dia.

Coro: Santa Rosa, madre mia, hoy se celebra tu dia.

Solista: A cazar salió don Jorge, a cazar como solia

Coro: Santa Rosa, madre mia, hoy se celebra tu dia

Solista: Lleva los perros cansados y el jurón herido iba

Coro: Santa Rosa, madre mía, hoy se celebra tu día

Solista: Se le oscurecio la noche en una oscura montiña etc.

El solista es siempre un hombre y suele, a la vez, tocar el tambor. El coro lo forman hombres y mujeres, indistintamente, y en número tan variado como se quiera. Nadie tendrá problema para cantar en el coro: la música es siempre la misma y la letra la que previamente ha propuesto el solista como pie. ${ }^{52}$ Pero no todos los del coro cantan en el mismo tono; cada uno lo hace en el suyo y se forma así una polifonía desarmónica con aires de lamento primitivo. $Y$ mientras el coro responde tocan el tambor, indistintamente también, hombres y mujeres. Los del coro se colocan en círculo alrededor del solista, pero sin mucho orden. Los que tocan las chácaras -sólo hombres- van al lado de los tocadores, y bien bailan y tocan o sólo tocan, pero nunca

s2 Normalmente basta una sola vez; sólo cuando el solista advierte indecisión en el coro lo repite 2 ó 3 veces. Por lo demás, los pies, cuando no son inventados en ese mismo momento, son fácilmente asimilables, pues la mayoría de las veces pertenecen al patrimonio común que todos los gomeros conocen. 
cantan. E inmediatamente a continuación de las chácaras, en filas enfrentadas de hombres y mujeres, los bailadores. Los bailadores no siempre respetan esta colocación de hombres frente a mujeres, pero todos bailan con las manos en alto, ligeramente doblados los codos, los que tienen chácaras tocándolas y los que no las tienen repiqueteando los dedos imitando el ritmo de las chácaras. Cuando un bailador se cansa pide el relevo y en su lugar sale otro, hombre o mujer, lo que corresponda, hasta que acaba el romance, y cesan entonces los cantadores, los tocadores y el baile. El baile es una sucesión de saltos de derecha a izquierda y de izquierda a derecha en cada mudanza. Es un juego de pie y talón con ambos pies, alternado, que se sucede cuatro veces y que al quinto paso, cuando un pie está en alto, se hace la mudanza y se retrocede lateralmente otros cuatro pasos. Así, pues, se forman dos cuerpos bien diferenciados: por una parte los cantadores y los tocadores de tambor, y por otra los bailadores y los tocadores de chácaras. No hay canto sin tambor, pero sí puede haberlo sin baile y sin chácaras.

Nosotros dejamos la fiesta a las dos de la madrugada, pero los últimos cantaron hasta el amanecer. Eso fue el sábado, la víspera de la fiesta. El día principal fue el domingo, 21 de agosto. El pequeño pueblo de Las Rosas recibió ese día más visitantes de los que podía albergar. Y su pequeña ermita rebosó de fieles que oyeron con devoción la misa en honor de su santa patrona Santa Rosa de Lima. Pero la fiesta grande vino después, con la procesión de la santa. La sacan en andas cuatro mozos del pueblo. La imagen es mediana, de escayola, vestida con hábito de dominica, con una corona muy florida sobre su cabeza y una rosa de plástico en la mano derecha, tan bonita como cualquier santo. Los cohetes suben al cielo y estallan para festejar su salida y así lo harán espaciadamente en toda la procesión. Se detiene la imagen en el atrio para dar tiempo a que se organice la marcha. Teóricamente tendría que ser así: primero los bailadores abriendo el camino, luego los de las chácaras y después los tambores y cantadores; inmediatamente detrás, la imagen de la santa y detrás de ésta el cura revestido de celebración, las autoridades del pueblo y de la isla y ya, después, el público en general. Debe haber una tendencia a que se guarden dos filas bien ordenadas, pero a medida que la procesión avanza las filas se deshacen y la gente camina por donde puede, en grupos delante o detrás de la imagen, según les parezca. Y otros, los que no pueden subir la cuesta o no quieren someterse al paso lentísimo de la procesión, la contemplan desde los laterales poniéndose en pie y descubriéndose con devoción cuando la santa pasa por delante de ellos. No es que se pueda hablar de desorden, sólo de acto familiar, ajeno a un protocolo limitador de la espontaneidad. Para unos la procesión será demostración de fe y devoción, para otros, yo creo que 
para la mayoría, demostración folklórica, oportunidad pública de reencontrarse con unos usos que han hecho sus antepasados y con unas costumbres que ellos mismos practican cada año. Aquí no se viene a cantar como en todos los demás sitios eso de

Dios te salve, salve María,

llena eres, eres de gracia...

sino romances del pueblo, los mismos que se cantaron la noche anterior en la plaza, o los mismos que se pueden cantar en casa haciendo la labor a en el campo cultivando la tierra. Y no hay en ello paganismo ni desacralización de nada; hay, eso sí, un entusiasmo ferviente a unos ritos profanos que se realizan dentro de una manifestación religiosa. Eso es todo. Los bailadores se han ido preparando ya en filas enfrentadas de hombres y de mujeres, sin ninguna vestimenta especial, con la camisa o el vestido de siempre; serán ahora unas diez o quince parejas, pero a lo largo de la procesión se suman otras hasta llegar a contar una veintena extendidas hasta unos treinta o cuarenta metros por delante de la imagen. De tambores habrá unos seis o siete y de chácaras unos cinco o seis.

Empieza a moverse la imagen y empiezan los tambores a sonar; las chácaras les siguen y los bailadores empiezan también sus pasos de danza. El solista canta ahora el romance de Lanzarote y el ciervo del pie blanco -un espléndido romance que parece tener en La Gomera su refugio después de haber desaparecido casi totalmente del resto de la tradición hispánica: una verdadera reliquia- con un estribillo cualquiera:

Verde montaña florida, el verte me da alegría.

El baile es brioso y exige resistencia; muchos empiezan a sudar y tienen ya las camisas por fuera, pero no decaen; las manos las ponen en alto, los brazos un poco doblados, como si estuvieran tocando las chácaras. En realidad así debía ser: todos los bailadores eran, además de bailadores, tocadores de chácaras. Algunos de los que las llevan bailan también y sus repiques secos y sonoros coinciden exactamente, más que con los golpes del tambor, con los pasos de la danza. Se nota que estos tocadores de chácaras son también los mejores bailadores. Los que tocan el tambor no bailan nunca, ellos van sólo arropando a los que cantan, ellos son también cantadores. Cogen su tambor con la mano izquierda, colgado el aro del dedo índice, y golpean con un palo con la mano derecha por la parte inferior del tambor, que queda inclinado por encima de la cintura. Tocan todos al unísono y todos 
cantan también el responder. El solista, el que canta el romance, lleva también su tambor, que le sirve para acomodarse al ritmo impuesto desde el principio. Así se forman dos cuerpos bien diferenciados: por una parte los bailadores y los de las chácaras y por otra parte los cantadores y los del tambor. Los que bailan, de ninguna manera pueden oír la voz del romanciador, pero sí que oyen las chácaras $y$, más lejanamente, los tambores. La cuesta hace que la procesión se estire y que cuando ya algunos bailadores estén arriba del todo la imagen y quienes la siguen estén aún a mitad de la cuesta. Pero no se para ni el baile ni la música.

Cuando el solista primero acaba su romance otro solista empieza el suyo, y luego otro, y otro, así hasta el final de la procesión que recorre el pueblo, cuesta arriba y cuesta abajo, y que se asoma a los linderos formidables del monte del Cedro. Los romances que sucedieron al de Lanzarote fueron el de El caballero burlado, el de Rosaura la del guante y el de Sildana. ¿El romance de Sildana? ¿Un romance de incesto en una procesión religiosa? ¿Qué irá pensando Santa Rosa? Menos mal que las pretensiones del padre incestuoso van matizadas por un pie que dice:

Si Santa Rosa me guía el cielo y la gloria es mía,

y que lo que la gente canta y lo que la gente oye es solamente eso:

Si Santa Rosa me guía el cielo y la gloria es mía.

porque Avelino, el que canta ahora, es un viejo con una voz cascada que se ahoga con el ruido de los tambores. Pero los que oigan a Avelino y los que conozcan el romance se preguntarán, sin duda, cómo la tradición ha podido unir en un mismo acto un romance de incesto y una procesión religiosa. Y Avelino sigue cantando aquellos versos sin el menor pudor, alzando la voz cada vez más, como quien se sabe protagonista de un momento que ha de perdurar y trascender a aquella mañana:

-Vaya usted mi padre al cuarto, que voy a cambiarme el traje y a quitarme las de oro vaya a mi cama floría, y a cambiarme las camisas y usar las de plata fina.

Cuando la procesión acaba su recorrido y la imagen llega de vuelta al atrio de la ermita se detiene allí hasta acabar el romance que están cantando. Los voladores se incrementan ahora y la campana de la ermita se voltea con más fuerza. Allí se reza una nueva oración y la imagen entra definitivamente dentro. 
¿Ya todo se acabó? Sólo de momento. Ahora viene el descanso para el almuerzo y para el coloquio con los parientes y amigos. $Y$ después del almuerzo y el descanso volverán de nuevo el canto y el baile. Por la tarde los tambores volverán al lugar de ayer por la noche, al lateral de la ermita, resguardados del bullicio de los altavoces. Y espontáneamente el baile se va nutriendo de los de siempre y de los de ahora, nuevas voces, nuevos bailadores, algún nuevo solista. Así hasta el anochecer, hasta que las gargantas no responden ya a la altura de la música y los pies no pueden seguir el ritmo profundo y ancestral de los tambores.

\section{LOS INSTRUMENTOS QUE SE UTILIZAN EN EL BAILE DEL TAMBOR}

La verdad es que el baile del tambor gomero posee pocas originalidades respecto a los instrumentos: un tambor y unas castañuelas gigantes llamadas chácaras. ${ }^{53} \mathrm{Si}$ acaso, el número de ellos que nunca está limitado y el tamaño de las chácaras, al estilo de las de Baleares y de las de los "vaqueiros de alzada" asturianos de las brañas del interior, ${ }^{54}$ pueden resultar novedosos.

a) El tambor. El tambor gomero es de doble parche y mide entre 20 y $30 \mathrm{cms}$. de diámetro y entre 10 y $15 \mathrm{cms}$. de altura. Tiene un aro circular muy saliente del parche que es por donde se agarra al tocarlo. Posee además un hilo de cobre que atraviesa el parche inferior para que el tambor retumbe cuando se toca. Se coge con la mano izquierda, a la altura del pecho, por la parte inferior, por la cara donde está el hilo de cobre, y se toca con la otra mano con una baqueta de madera golpeando sobre el parche y rascando sobre el aro. $\mathrm{La}$ sonoridad es muy grande en proporción a su tamaño, teniendo ese especial timbre que le da el retumbar del hilo de cobre.

Se fabrica artesanalmente en la propia isla, de la forma siguiente: ${ }^{35}$

s3 El tambor, las castañuelas, los panderos y la pandereta son, por lo demás, los instrumentos típicos de los demás bajles romancescos, prueba de su rusticidad y arcaísmo.

s4 "Denominase así cierta clase de gentes de la población asturiana que viven, principalmente, de la cría de ganado vacuno, y que, por exigencias del clima, se ven precisadas a emigrar a distintos sitios de la provincia, a principios de invierno y verano, buscando el pasto para sus rebaños. Los vaqueiros viven aislados del resto de la población de Asturias, la cual les considera despectivamente, como gente de raza distinta e inferior" (Eduardo M. TORNER, Cancionero, p. 208, nota 1).

55 Estas notas sobre la fabricación del tambor y de las chácaras se las debemos a Luciano Conrado Cordobés, de La Palmita (Ayunt. Agulo), extraordinario artesano y extraordinario cantor también de romances. 
-Se elige y prepara la madera para los aros y para la caja, madera de mimbre o de saro, madera delgada y flexible. Se clavan los aros y la caja por separado.

-El parche es de piel de animal: la mejor la de cordero o la de oveja; de menor calidad la de baifo (cabrito), conejo o perro; la de cabra no sirve por su excesivo grosor.

-La piel no se curte, simplemente se deja secar bien, remojándola después y raspándola para quitarle el pelo.

-Así la piel, se envuelve en dos anillos de madera que se encajan en la caja y se sujetan a los aros.

-Los aros se sujetan entre sí por una cuerda "empichada" (engrasada o con brea) que se trenza alrededor del tambor en forma de zigzag.

-El hilo de cobre que atraviesa el parche inferior se sujeta fijo a un extremo del arco y al otro a una clavija que regula su tirantez.

- La baqueta para tocar suele ser de madera de brezo, relativamente corta y gruesa, terminando en una pequeña bola, y se sujeta con una cuerda al aro "para que no se pierda y no ande rodando por ahí".

b) Las chácaras. Son castañuelas gigantescas, de hasta $10 \mathrm{cms}$. de diámetro, y de forma abombada casi esféricas. Su sonoridad es extraordinaria. Se tocan por parejas, es decir, una pareja en cada mano. Dado el considerable peso que tienen (son de madera maciza) han de sujetarse a los dedos de una forma especial: las cintas pasan en una primera vuelta por los dedos índice, corazón y anular, y en una segunda vuelta por estos tres y el meñique. Cada chácara produce un sonido diferente: la de sonido más agudo (la hembra) lleva un repiqueteo constante y es la que "canta", la de sonido más grave (el macho) hace de contrapunto y sirve para acompañar.

En su elaboración se utilizan maderas de distintas clases: castaño, brezo, viñátigo, etc., pero la mejor es la de moral, que produce el sonido más seco y que, al no tener hebras, no se raja. El trabajo mayor lo requiere el hueco central del interior de las chácaras: de él depende su sonido y por él se conoce a su artesano. Los hay que trabajan a punta de navaja y los hay que se ayudan de un berbiquí o de un taladro eléctrico. La finura de su relieve y el color final de las chácaras, a gusto del artesano.

La palabra chácara se utiliza también en la isla del Hierro para designar las castañuelas que alli se tocan, pero son mucho más pequeñas que las de La Gomera. En el resto de las islas se utilizan otros tipos de castañuelas de tamaño normal, pero no se usa la voz chácara. En torno a esta voz se han expuesto varias teorías: la de quienes creen que se trata de una onornatopeya, la de quien dice que deriva del antiguo castellanismo xácara ('baile', y de ahí 'instrumento 
utilizado en el baile') y la de quien afirma que es un americanismo indigena. ${ }^{56}$

\section{LOS ROMANCES QUE SE CANTAN}

Cada una de las danzas romancescas de la Península se ejecutan (ejecutaban) al son de uno o de varios romances determinados. Así, en la danza prima asturiana es característico el Ay un galán de esta villa, en el corri-corri de Cabrales los de Rosaura la del guante y Doña Josefa Ramirez, en el pericote de Llanes algunos romances religiosos y, sobre todo, el de Espinela, en el baile a lo llano de Ruiloba el de La condesita, en el baile de tres de Las Navas el de Gerineldo y en La charrada de Peñaparda La malcasada y La apuesta ganada. En Canarias no ocurre lo mismo. Con el baile del tambor de La Gomera se cantan (o se pueden cantar) todos los romances. Y eso es también lo que debió ocurrir en la isla del Hierro con la meda (aquí ha permanecido el canto pero no el baile) y en la de La Palma hasta fechas muy recientes con el jila-jila. Asi que las islas más occidentales de Canarias poseen una característica común bien diferente del resto del Archipiélago y de España. En El Hierro y en La Palma a la música de los romances se le llama la meda, en La Gomera el tambor, pero las tres islas cantan los romances con un mismo modelo musical, de ahí que lo que hoy tiene plena vigencia en La Gomera debiera tenerlo también, por analogía, en tiempos pasados en las otras islas occidentales. El resto de las islas se comportan de forma muy diferente en lo musical: cada romance se canta con su música particular, como ocurre en la Peninsula.

Durante los dos días que estuvimos en el pueblo de Las Rosas presenciando el baile del tambor, pudimos constatar lo que ya antes nos habian dicho reiteradamente nuestros informantes: todos los romances se cantan igual y todos los romances sirven para el baile. En esos dos días oímos cantar y vimos bailar romances "viejos" tales como Lanzarote y el ciervo del pie blanco o El caballero burlado, romances "de pliego" tales como Rosaura la del guante o Inés de Puertocarrero, romances vulgares "de ciego" sobre sucesos modernos tales como La criada Tomasa (sobre un crimen cometido en la provincia de Huelva) o Gertrudis, la niña perdida, romances de tema local y romances de tipo religioso tales como La huida a Egipto (o El milagro

56 Esta última es la que sostiene Elfidio Alonso, quien dice que instrumento y palabra "vienen por línea directa de los crótalos de los curanderos negros (cubanos) a los que se llama precisamente chacareros" (E. ALonso, Tierra Canaria, fasc. 5, s.p.). Tal afirmación es insostenible pues las castañuelas son instrumento desconocido en el folklore de los negros. 
del trigo) o La Pasión. Es decir, todos. Los que no se cantan nunca en el baile del tambor son los que allí se llaman "rezados", es decir, algunos romances religiosos y las oraciones romanceadas tipo $\mathrm{La}$ Virgen camino del Calvario o El discípulo amado y las tres Marias. Otro grupo de romances se cantan pero no se bailan: son los del repertorio infantil, tales como La doncella guerrera, El conde Niño, El quintado o Santa Iria, y los que suponen para los gomeros "chistes" o "cosas de broma", como El gato y el ratón o Romance encadenado. Se cantan, sí, pero cada romance con su música, como en cualquier otro lugar de España, y se descartan del baile del tambor por razones obvias: los no octosilábicos y los de rima estrófica cambiante porque no se adaptan al molde invariable y fijo en ritmo y medida del baile, y los de gusto infantil por ser exclusivos del folklore de los pequeños.

Una de las notas más extraordinarias del romancero de La Gomera es la plenitud de sus versiones, quiero decir las versiones tan íntegras y completas que alli se cantan. Cuando, por lo general, en otros lugares lo más que se consigue en las encuestas romancísticas son fragmentos o versiones llenas de lagunas de memoria del recitador, de versos que faltan, en La Gomera, no ya en el canto, ni siquiera en una recitación, es muy improbable que el transmisor ofrezca una versión en donde falte algo. La razón no puede ser otra que la continua actualización en la que vive el romancero en la isla gracias a su utilización para el baile: la memoria está así lista para ofrecer en cualquier momento un texto integro y perfecto. El romancero vive de verdad en La Gomera y no sólo es recuerdo o nostalgia. Es sintomático además el comportamiento generalizado de los cantores de romances gomeros: cuando se les pregunta por un romance determinado que ellos lo saben a medias, prefieren callarse del todo, piensan que sería un deshonor en la tierra del romancero decir algo incompleto, palabras sueltas, historias rotas, cuando otros muchos conciudadanos suyos lo saben íntegramente. Así que preferirán decir: "Ese romance que usted me pregunta lo sabe Fulano". Y en efecto así será: Fulano sabe ese romance. Lo que quiere decir que los cantores de romances gomeros se conocen entre sí, conocen su propio repertorio y saben del repertorio de los demás. Por algo el canto es público y se manifiesta a diario.

\section{SOBRE EL ORIGEN DEL BAILE DEL TAMBOR}

Advierte L. Siemens en un breve y panorámico estudio sobre la música en Canarias, refiriéndose al baile del tambor, que la forma en 
que llegó esta danza a Canarias y fue adaptada por el pueblo es algo todavía por investigar. ${ }^{57} \mathrm{Sin}$ embargo, las opiniones a este respecto se dividen entre quienes postulan un origen europeo y los que afirman unas raíces autóctonas o africanistas. Así, el propio L. Siemens sostiene que el baile del tambor o tajaraste "es un baile ejecutado sobre un corto esquema rítmico muy característico cuya estructura es bien conocida en relación con los antiguos ritmos populares de tambor y, en particu. lar, con el de una popular danza barroca europea llamada precisamente "le tambourin". ${ }^{58}$ Por contra, J. Crivillé dice que "el baile del tambor posee una de esas músicas de probable origen prehispánico que han conservado, en su esencia, todo un sustrato etnomusical de elevado valor histórico. El ritmo obsesivo, la monotonía del lenguaje, la parquedad de las cadencias melódicas y la acusada referencia al erotismo que tienen los pasos coreográficos del baile del tambor inducen a pensar a algunos en cierto africanismo musical". ${ }^{59} \mathrm{La}$ teoria africanista o indígena es asumida incluso a nivel popular y de opinión por personas no especialistas. ${ }^{60}$

En fin, puesto que en el baile del tambor confluyen elementos muy diversos: el texto, los instrumentos, la música, el baile y el silbo, conviene analizarlos por separado.

a) El texto que se canta. Lo que se canta son siempre romances castellanos acompañados de un estribillo o pie de romance. El pie es canción lírica de creación popular y no, como dice E. Alonso, "antiguos restos de romances". 61 Algunos pies son ya patrimoniales y, por lo tanto, conocidos y usados por todos, por ejemplo:

57 L. Siemens Hernandez, La música en Canarias, p. 49.

sk Ibid., p. 49.

59 J. CRIVILLE, El folklore musical, p. 262.

to Son interesantes, por curiosidad, las notas que dos estudiosos gomeros, de Hermigua, Jesús Trujillo Trujillo y Salvador Espinosa Ayala, prepararon para la presentación del Grupo folklórico de Hermigua (el de Lydia Ascanio) en un Concurso Nacional de bailes de la Sección Femenina en Madrid en 1956: "El baile del tambor-dicen-tiene el ritmo básico de la danza de los aborigenes de la isla de La Gomera, ejecutado al ritmo monotónico de primitivos tambores, no provistos de cuerda metalica que poseen los acluales pues eran desconocidos los metales en la isla, conservado por tradición. Es de suponer -siguen diciendo los de Hermigua- que después de la Conquista y de la suponer -siguen diciendo los de ter por ella surgió un nuevo ritmo acelerador de la monotonia básica y que en la práctica actual se confunden y amalgaman con el primitivo monolonia básica y quelista como puede oirse. Y por último-acaban los comentaristascon la incorporación del romance castellano, por la expansión del espiritu popular al ritmo básico, ha producido la modalidad de la marcación silábica acudiendo al recurso de intensidad y tiempo venciendo la monotonia instrumental".

6I E. Alonso, Tierra Canaria, fasc. 5, s.p. 


$\begin{array}{ll}\text { Hice una raya en la arena } & \text { por ver el mar donde llega } \\ \text { Son tus ojos, linda dama, } & \text { luceros de la mañana } \\ \text { Con agua clara y corriente } & \text { mi corazón se divierte }\end{array}$

Otros, por el contrario, son invención momentánea del solista para el canto de un romance concreto, por ejemplo:

\author{
Vine a ver a Santa Rosa \\ Bajó del cielo a la tierra \\ Forastero en tierra ajena
}

\begin{abstract}
una santa muy preciosa ${ }^{62}$ un alma a pagar su pena ${ }^{63}$ por bien que le vaya pena ${ }^{64}$
\end{abstract}

Pero los romances son textos absolutamente españoles que llegaron a Canarias desde los primeros años de la Conquista y se asentaron en la cultura popular de las islas de la misma forma que lo hicieron en los otros lugares del mundo hispánico a donde los españoles llegaron en algún momento de la historia. Yerran por completo, pues, los que creen que las historias que se cuentan en los romances tradicionales son de héroes guanches o de luchas entre canarios y españoles conquistadores o de leyendas prehistóricas. Los romances que se cantan en La Gomera -y en Canarias en general- son los mismos romances populares que se pueden oír cantar en Galicia, en León, en Portugal o en América. ${ }^{65}$ Los que sí se cantan también en La Gomera son los romances de tema local modernos (una desgracia local, un crimen, unos amores famosos, una catástrofe natural), pero éstos han sido hechos al modo y manera de los tradicionales, tratando de imitarlos en todo, en la versificación, en el lenguaje, en los diálogos, en sus dimensiones, en todo. $Y$ además, los romances de tema local son absolutamente insignificantes en cuanto a número respecto del formidable repertorio del romancero tradicional que vive en $\mathrm{La}$ Gomera: ningún cantor gomero buen conocedor de su tradición preferirá nunca el canto de un romance local al de un romance viejo como el de Sildana, El caballero burlado o Blancaflor y Filomena.

62 Pie cantado en la fiesta de Santa Rosa de Lima, en el pueblo de Las Rosas, para cualquier romance que acabase en -óa.

${ }_{63}$ Pie cantado para acompañar al romance El difunto penitente a quien, sin duda, hace referencia.

64 Pie que oímos para acompañar al romance Blancaflor y Filomena, que resume a modo de moraleja lastimera.

65 Hay quien ha llegado a decir, naturalmente sin haber oído nunca el canto de romances, que "entre los cantos gomeros encontramos los cantares de gesta en los que rememoran a los antiguos valientes de la isla". Vid. Diego TALAVERA, Canarias, folklore $y$ canción, Madrid, Biblioteca Popular Canaria, 1978, p. 19. 
b) Los instrumentos. La doctrina asentada por ahora entre los especialistas en torno a los instrumentos musicales utilizados por los aborigenes canarios es de que eran de una pobreza extrema. "Lo cierto es que los cronistas más antiguos - dice L. Siemens- nos refieren que los aborigenes carecían de instrumentos, y que sus sones eran producidos solamente cantando y con la primaria percusión de pies y manos". ${ }^{66} \mathrm{Si}$ bien la arqueologia y otras ciencias afines a la etnomusicología han podido interpretar algunos restos arqueológicos como primitivos instrumentos musicales: así una especie de silbato hecho sobre un hueso de animal, collares de caracolillos usados probablemente como instrumento sonoro en las danzas rituales, algunas espátulas de hueso con función de zumbaderas, y poco más.

Por lo que respecta al tambor gomero dice L. Siemens: "El tambor de cualquier tipo no sólo es desconocido en las crónicas más antiguas (de Canarias), sino que ni siquiera los restos arqueológicos nos deparan, entre lo encontrado hasta ahora, nada que pueda asemejársele". $A$ " Así que cuando se habla de "primitivos tambores de los aborigenes" ts a lo más que podemos llegar es a imaginar un cierto tipo de percusion corporal, un batir de pies y manos o una especie de maracas "onde hacian zonzonetes con piedresuelas i tiestos de varro", como dice Gómez. Escudero en su Crónica sobre la conquista de Canarias, con referencia específica a los aborígenes de La Gomera. ${ }^{69}$

El tambor gomero es, pues, producto cultural español $y$ europeo. Otra cosa será que en La Gomera se haya adaptado a unos usos determinados con características especiales. Algún parentesco tiene con otros tambores de las islas, como el de La Palma que se utiliza en el baile del sirinoque o con el que se usa en el rancho de animas de Valsequillo, en Gran Canaria. Pero el parentesco es mayor -igualdad diríamos- con el que utilizan los pastores de Cuevas (Asturias), tanto en la forma del tambor como en la manera de tocarlo, tal cual se nos muestra en una fotografía antigua que reproducimos..$^{70}$ Y Cuevas está, justamente, en las cercanías del Puerto de Somiedo, la estacion veraniega de los "vaqueiros", en plena ruta "vaqueira".

66 L. Siemens Hernandez, La misica en Canarias, p. 17.

67 Ibid., p. 16.

or Nos referimos a las notas transcritas anteriormente de los dos estudiosos de Hermigua para la presentación del baile del tambor en Madrid.

6) Gómez Escudero, Historia de la conquista de Canaria, ed. de Francisco Morales PAdrón, Canarias: Crónicas de su conquista, Las Palmas, Ayuntamiento de Las Palmas de Gran Canaria y El Museo Canario, 1978, p. 435.

70 Publicada por F. CARRERA Y CANDY en su Folklore y costumbres de España, II, p. 82 
Y lo mismo tendríamos que decir de las chácaras. De aborígenes no tienen nada. Lo más probable es que sean importación directa de las castañuelas gigantes de los "vaqueiros de alzada" asturianos o de las zonas montañosas de León ${ }^{71}$ que podría explicarse por la venida a Canarias y a La Gomera de pastores de aquéllos, dadas las similitudes de relieve extremadamente montañoso del norte peninsular y de esta isla.

c) El baile. Pocas cosas tan difíciles de precisar como el origen e influencias de una danza tradicional, mucho más cuando, como en el caso de Canarias, a un sustrato aborigen probable se superponen elementos principalmente españoles (europeos) pero también, aunque secundariamente, elementos africanos (a través de moros y moriscos que trabajaron en las islas durante los siglos XVI y XVII como esclavos) $y$ americanos (debido al intenso intercambio que ha tenido siempre Canarias con el Continente desde el momento mismo del Descubrimiento). A lo que parece sólo una de las danzas que perviven hoy en el Archipiélago es indudablemente prehispánica, el sirinoque de La Palma, pero sólo en un cierto sentido, pues aunque contenga la esencia de la danza y la música del antiguo canario, éste pasó a la Península y a Europa donde se hizo cortesano y muy popular en los siglos XVI y XVII y de allí volvió de nuevo a Canarias ya matizado por el estilo adquirido en el continente. ${ }^{72}$

El que sólo se haya conservado uno de los antiguos bailes autóctonos canarios no quiere decir que otros de los actuales no posean algún rasgo o elemento de aquella procedencia. Desde luego el del tambor de La Gomera parece muy primitivo: falto de toda coreografía complica$\mathrm{da}$, no consiste más que en filas enfrentadas de hombres y mujeres que dan briosos saltos, pero no para acercarse y alejarse, lo que es característica de toda danza de requerimiento y rechazo, sino en movimiento masivo de vaivén, basculando las filas en sentido lateral, primero alejándose de los tocadores y luego retrocediendo hacia ellos. No tiene sentido, pues, la observación de J. Crivillé, quien obviamente sólo conoce el baile del tambor por referencias escritas, de que "la acusada referencia al erotismo que tienen los pasos coreográficos del baile del tambor inducen a pensar en cierto africanismo musical". ${ }^{73}$

$"$ Son especialmente interesantes aquí, por su aplicación, las notas que sobre las castañuelas de los "vaqueiros" ofrece J. M. FrAILE GIL en su articulo "Algunas notas sobre los instrumentos propios de los vaqueiros de alzada", en Revista de Folklore, n.0 36, Valladolid, 1938, pp. 204-211.

${ }^{72}$ Cf. L. SIEMENS HERnÁNDEZ, La mísica en Canarias, p, 25.

${ }^{3} \mathrm{~J}$. CRIVILLE, El folklore musical, p. 262. 
Claro que la simplicidad coreográfica y el aparente primitivismo de la danza gomera no son argumentos convincentes, por sí solos, para atribuirle un origen guanche, sin más.

Lothar Siemens, dando muestras una vez más de su perspicacia, apuntaba hace años un camino que, a pesar de lo extraño, orienta certeramente sobre la génesis del baile gomero. Afirmaba que el baile del tambor era "una danza de marcadas concomitancias astúricas". ${ }^{74}$ Faltaba todo comentario adicional que justificase tal afirmación, bien es verdad que en una publicación de tipo divulgativo, pero abría una pista digna de explorarse. ${ }^{75}$

Hasta aquí hemos venido refiriéndonos repetidamente a la región asturiana como ciertamente conservadora en relación a los mismos fenómenos que estudiamos en La Gomera: la pervivencia de varios bailes romancescos y la similitud de los instrumentos que utilizan los "vaqueiros de alzada" con los que se usan en el baile del tambor. Será necesario ahora detenernos un poco más en esto.

Los "vaqueiros" tienen como baile típico el baile del pandero. Así lo describió en 1920 Eduardo M. Torner, a quien todos copiarán después: ${ }^{76}$

Canción de baile de pandero. Es propia de los vaqueiros de alzada que habitan las brañas vecinas a Somiedo. Este baile es muy general en Asturias, y su ritmo casi exclusivo es el de seis por ocho. Para ejecutarlo, se distribuyen hombres y mujeres en dos hileras respectivas y colocadas frente a frente. Cada bailador está provisto de castañuelas, cuyo tamaño varía según el sitio de la provincia, pues hacia la costa y en la parte central, no excede de unos cinco centímetros de diámetro, mientras que en el Sur, y sobre todo en los pueblos que limitan con León, pueden tener triple o cuádruple tamaño. Detrás de una de las hileras de

74 L. Siemens Hernández, La música en Canarias, p. 35.

75 A tal conclusión llegó después de ver bailar por TVE a un grupo folklórico de una zona montañosa de Asturias, sin poder concretar entonces el nombre del baile, la zona de la que procedía ni el grupo folklórico.

76 Eduardo M. Torner, Cancionero, cit., pp. 208-209; y, entre otros, A. CAPManY, El baile y la danza, cit., pp, 242-243. También es cierto que quienes han estudiado los "vaqueiros de alzada" se han preocupado más por otras cuestiones históricas y etnológicas que por su folklore y aun dentro de éste por sus canciones - "las vaqueiras"- más que por su típica danza del pandero. Cf., entre otros, ACEvedo y HuElves, Los vaqueiros de alzada en Asturias, Oviedo, 1915; Ramón Baragaño, Los vaqueiros de alzada, Oviedo, Col. Popular Asturiana, 1977; Modesto GONZÁLEZ COBAS, De musicología asturiana: La canción tradicional, Oviedo, IDEA, 1975; José Benito A. BuYlLA, La canción asturiana, Oviedo, Col. Popular Asturiana, 1977; y, sobre todo, el gran estudioso de los "vaqueiros", Juan URIA RiU, Los vaqueiros de alzada, Oviedo, Col. Popular Asturiana, 1976, y J. Manuel FraIle GIL, "Algunas notas sobre los instrumentos propios de los vaqueiros de alzada", en Rev, de Folklore, 36, Valladolid, 1984, pp. 204-211. 
bailadores se sitúa la cantadora, la cual toca el pandero al mismo tiempo que entona las coplas. El pandero es de forma circular, mas se usó en otro tiempo, como aún hoy en la parte alta de León, un pandero cuadrado cubierto con piel por ambos lados y cuyo bastidor estaba cruzado interiormente por cuerdas de tripa de cordero, a fin de hacer más intensa la vibración. Mientras se canta la copla, suena el pandero suavemente en un aire moderado y los bailadores hacen el paseo, esto es, imprimen al cuerpo un movimiento rítmico hacia los lados, conservando los brazos en posición natural. Al terminar la cantadora la copla, dan aquéllos una vuelta completa girando sobre los pies, y levantando los brazos, comienzan a bailar acompañándose con las castañuelas, al mismo tiempo que el pandero suena con mayor intensidad y en aire algo más acelerado. Los movimientos del baile son sencillos, limitándose, por lo general, a un simple y alternativo cruzado de pies en cada parte del compás, salvo cuando alguno de los bailadores quiere hacer alarde de su destreza y complica cada vez más los movimientos.

Los ritmos de pandero y castañuelas más usados son los siguientes:
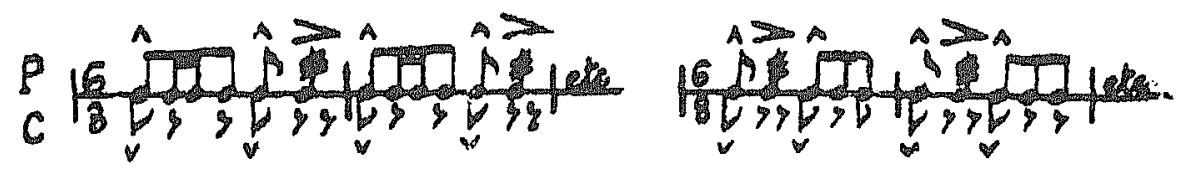

Comparados ahora, punto por punto, el baile del tambor de La Gomera y el baile del pandero de los "vaqueiros" asturianos esto es lo que los emparenta:

a) El mismo compás de $6 / 8$.

b) El mismo ritmo de castañuelas y de tambor (los "vaqueiros" usan pandero, y de ahí el nombre de su baile).

c) Igual colocación de los cantadores respecto al cuerpo de baile.

d) Unos mismos movimientos coreográficos: desplazamientos laterales de las filas de bailadores.

e) Filas enfrentadas de hombres y mujeres.

f) Unos mismos "pasos" individuales.

g) Bailadores provistos de castañuelas.

h) Castañuelas gigantes - muy raras- en ambos bailes.

i) Cantadores que, a la vez que cantan, tocan el tambor o el pandero.

Lo que los diferencia es, desde luego, mucho menos y mucho menos importante. Afecta más a los complementos del baile que al baile mismo: 


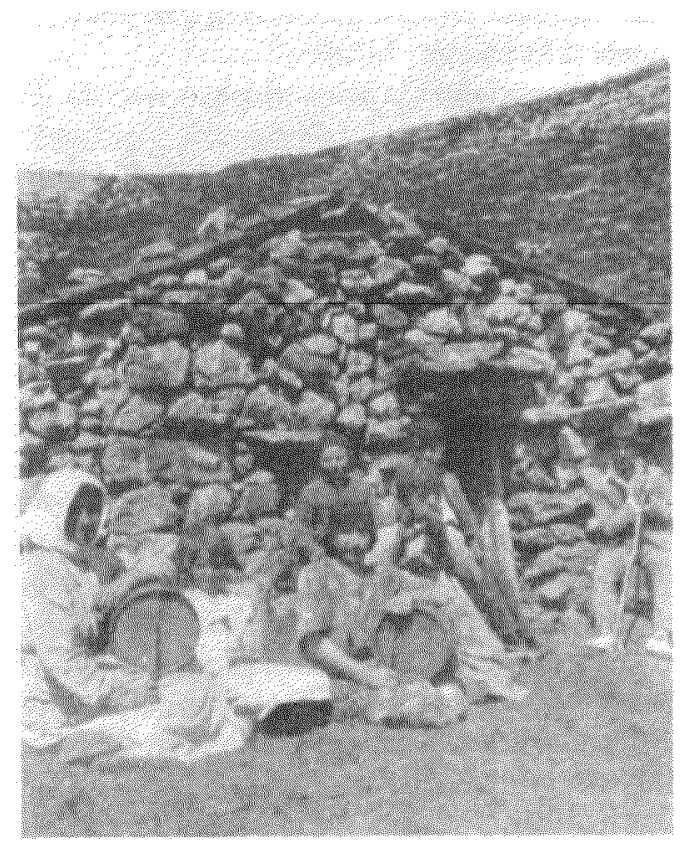

Fic. 7. Pastores de Cueva (Asturias), en el Puerto de Somiedo, en plena ruta "vaqueira", cantando y tocando el tambor ante una choza. El parentesco del tambor "vacueiro" con el gomero es asombroso, como lo es tambien el tipo de construeción de chozas en piedra seca. (Fotografia tomada de Folklore y Costumbres de España, II, p. 82)

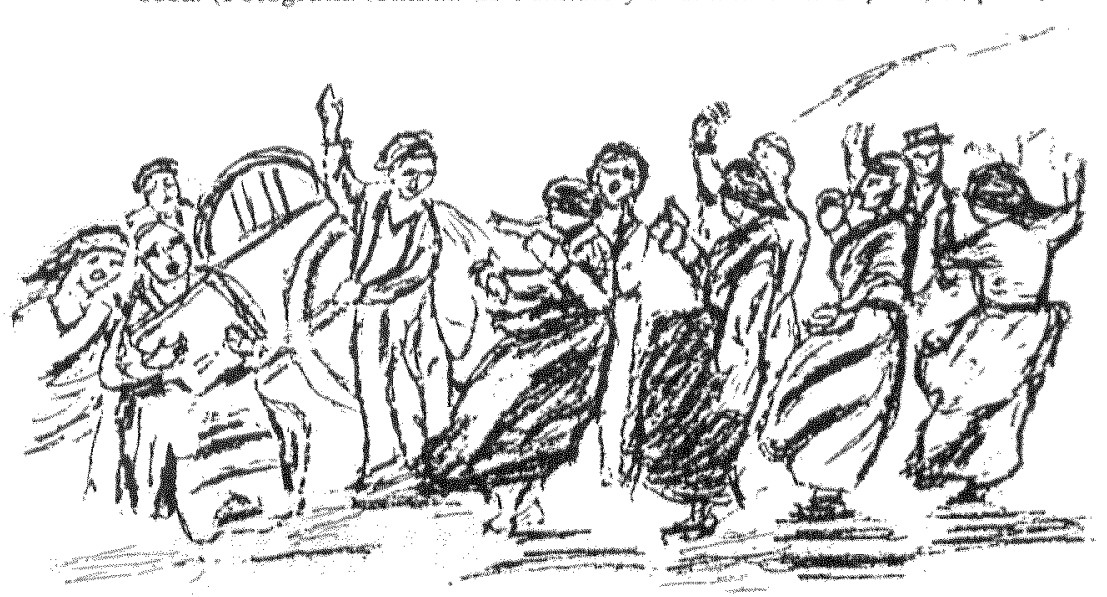

Fic, 8. El baile del pandero de los "vaqueiros de alzada" asturianos, segun apuntes tomados de la portada del disco de Juan Uria Maqua, Vaqueiradas 
a) La utilización de un pandero en el baile del pandero y de un tambor en el del tambor es circunstancia irrelevante; ambos instrumentos pertenecen a la misma familia.

b) La melodía, aunque no la característica de la estructura rítmica sobre la que está montada.

c) El tipo de texto que se canta y la forma de cantarlo.

¿Se trata de un mismo baile o de dos bailes parecidos? O de otra forma: ¿El baile de La Gomera procede del de los "vaqueiros" o es manifestación autóctona llegada independientemente a la misma configuración que la de los asturianos? Demasiadas "coincidencias" para haberse desarrollado de forma independiente cada uno por su lado. Demasiados elementos para unirse "casualmente" dos tipos de conjuntos tan alejados geográficamente. Porque por encima de cada uno de los elementos particulares hay un conjunto folklórico que es muy difícil explicar sin un contacto de los pueblos que lo practican. El contacto entre los "vaqueiros" y los de La Gomera está sin explicar. Habría que investigar el tipo de repoblamiento de las Islas Canarias para ver si, como es probable, llegaron aquí gentes provenientes del norte peninsular para dedicarse al pastoreo, pensando en la mucha similitud que tiene la orografía extremadamente montañosa de La Gomera (y de las islas en general) con la de Asturias y lugares habitualmente utilizados por los "vaqueiros". Cierto que el baile del pandero no es romancesco y que lo que los "vaqueiros" cantan son simples coplas octosilábicas como éstas:

Este pandeiro qui tocu yes de pitseyu d'ubecha, ayer birraba n'el monte giiey toca que ritumbietsa.

Avivai las castañuelas, mozas del baile primero, avivai las castañuelas que yo avivaré el pandeiro.

Pero ésa no es circunstancia excluyente, porque o bien el baile de los "vaqueiros" pudo ser en un principio romancesco -circunstancia que se conservó en La Gomera y que se perdió en Asturias 77- o bien el canto de los romances se añadió en La Gomera a la danza, sin más aditamento que un coro capaz de responder a cada frase del solista.

77 Otros muchos bailes fueron antes romancescos y pasaron después a ser líricos. Esto es justamente lo que está ocurriendo ahora, por ejemplo, con el pericote de Llanes o con la danza prima asturiana. 
Además, la geografía de los bailes romancescos pone inexcusablemente en contacto directo Asturias y Canarias: Una simple relación de los que han llegado hasta los tiempos modernos reparten la geografía, casi con exclusividad, entre Asturias (la danza prima, el corri-corri y el pericote) y Canarias (el del tambor de La Gomera, el jila-jila de La Palma y la meda del Hierro). Los que conocemos fuera de Asturias y de Canarias son sólo tres: el de Ruiloba (Santander), fácil de explicar por la proximidad geográfica con Asturias, el de Las Navas del Marqués (Ávila) y el de Peñaparda (Salamanca), con indudable parentesco con el norte peninsular, pues no en balde la zona de El Rebollar y sur de Salamanca es repoblación astur-leonesa, que conserva rasgos dialectales del antiguo leonés y que utiliza para su baile típico, la charrada, un instrumento típico del norte, el pandero cuadrado. Además, la charrada coincide básicamente, y a grandes rasgos, con el fenómeno del baile de los "vaqueiros" asturianos y del tambor de La Gomera: a) posee un compás ininterrumpido de $3 / 8$ batido sobre tambor o pandero, b) se adopta una fórmula melódica que abarca un periodo repetitivo de 16 sílabas, y c) existe una misma disposición coreográfica de los bailarines en filas enfrentadas de hombres y mujeres, encabezadas siempre por el tocador-cantador, en este caso la "panderera". Por lo demás, los corridos andaluces fueron olvidados completamente en el siglo XIX.

d) La música. Quienes con oídos profanos y ajenos a toda crítica musical hayan oído alguna vez a un grupo de gomeros cantando sus romances, la impresión más sobresaliente recibida habrá sido, sin duda, la de asistir a un canto lamentoso, un puro gemido desgarrador; esto sobre todo en las partes en las que el coro canta el pie o estribillo en conjunción totalmente inarmónica, como si de un mismo gemido dicho por varias gargantas y de varios modos se tratara; pues aunque la estructura melódica se respete no así el tono ni las leyes del canto coral, que cada uno canta a su manera, sobresaliendo los unos sobre los otros. E interesa decir aquí que esta impresión no es sólo la que podamos tener ahora, es también la que tuvieron los primeros cronistas al describir los cánticos de los canarios aborígenes o de sus descendientes:

Cantaban canciones sentidas i lastimeras, i repetían una cosa muchas veses a modo de estrivillo, $i$ esto usaban mejor los Gomeros, porque oiendo cantar solían enternecerse y llorar si la cosa era trajica y lastimera. ${ }^{78}$

78 P. Gómez Escudero, Historia de la Conquista de Canarias, cit., p. 435. 
Esto decía Gómez Escudero refiriéndose a los gomeros. Bien es verdad que la Crónica de Escudero es una recreación muy tardía (de mitad del XVII), y ampliada, de la primitiva Crónica de la Conquista de Canarias, hecha probablemente al filo de los hechos de la conquista por don Alonso Jaimes de Sotomayor, alférez mayor de la conquista de Gran Canaria, ${ }^{79}$ y que el pasaje que transcribimos es justamente una de las ampliaciones de Escudero no contenida en la Crónica primitiva. Se trata, pues, de la impresión que un hombre del siglo XVII tiene sobre los cánticos de los gomeros del XVII, aunque se atribuya a los cánticos y a los gomeros del tiempo de la conquista (siglo Xv).

Pero a decir verdad, lo que Gómez Escudero hace no es sino repetir algo que se había hecho tópico en la historiografía canaria desde mediados del XVI: la extraordinaria languidez y tristeza de los cánticos de los aborígenes. Así quedó fijado, por vez primera, en la Crónica Matritense, una versión extractada, de mediados del XVI, de la "crónicamadre" desaparecida:

Hera gente afable y sus cantares muy lastimeros, cortos, a manera de endechas, y muy sentidos, y ahora los cantan en rromance castellano, que mueven a compasión a los oyentes. ${ }^{80}$

Y seguirá repitiéndose lo mismo, un poco más ampliado, también con referencia a los cánticos del Hierro, un siglo más tarde, a mitad del XVII, en la Historia del Lic. López de Ulloa:

Hera esta gente afable y dócil, y sus cantares muy lastimosos a manera de endechas cortas y muy sentidos, y oy en dia se cantan en lenguaje castellano que caussan y mueven a compassion y enternesen mucho y se a visto causar lágrimas a mujeres y personas de coraçón blando. Y si tratan de amores, ausencias, muertes y apartamientos mucho más. ${ }^{81}$

Y antes lo habian dicho también, con aplicación a otras islas del archipiélago, Torriani y Abréu Galindo. Leonardo Torriani era un ingeniero italiano al servicio del rey de España que vino a las islas para realizar un informe sobre las fortificaciones canarias y que escribió una valiosísima Descripción de las Islas Canarias y de los usos y costumbres de sus habitantes a fines del XVI. Esto es lo que dice del canto de los gomeros:

79 Cf. F. Morales Padrón, Canarias: Crónicas de su conquista, Introducción.

${ }^{80}$ Conquista de las siete Islas de Canarias ("Crónica Matritense"), ed. de F. Morales Padrón, Canarias: Cronicas de su Conquista, p. 232.

81 Historia de la Conquista de las Siete Yslas de Canarias, del Lic. LoPEz DE UlloA, ed. de F. Morales Padron, cit., p. 264 
Cantaban versos de lamentación, de ocho, nueve y diez sílabas, y con tanta tristeza, que lloraban ellos mismos, como se ve que todavía lo hacen hoy día los que descienden de los últimos habitantes... Es verdad que también se cantaban en las demás islas, con motivo de la muerte de alguna persona principal, o de algún triste suceso; pero las (endechas) de esta isla (La Gomera) eran más hermosas y más dolorosas. ${ }^{82}$

Y Abréu Galindo, franciscano de Las Palmas de Gran Canaria, que escribe en 1602 su Historia de la Conquista, la más abundante en datos sobre los canarios aborígenes, dice de los del Hierro:

Era la gente de esta isla muy triste, de mediana estatura. Cantaban a manera de endechas tristes en el tono y cortas. ${ }^{83}$

Y de los de Gran Canaria:

Sus cantares eran dolorosos y tristes, o amorosos, o funestos, a los cuales llamamos endechas. ${ }^{84}$

De lo que nos están hablando los cronistas e historiadores no es de los romances, sino de las endechas, ese género literario y musical "de Canarias" que se puso de moda en la Península desde la mitad del xvi hasta principios del XVII. De tal forma que, a lo que parece, las endechas fueron el único canto de los canarios que llamó tan poderosamente la alención de españoles y europeos. Así, pucde decirse que las notas comunes que se repiten sin variación en todos los textos son:

a) Las endechas eran cánticos de temática triste: amores, ausencias, apartamientos, muertes.

b) Eran tan lastimeros y enternecedores que hacían llorar a las mujeres y "a los de corazón blando". ${ }^{85}$

c) Se cantaban en castellano, aunque Torriani (y otros) recogieron algunos textos en lengua aborigen.

${ }^{82}$ L. TORRIANI, Descripción e historia de las Islas Canarias, ed. de Alejandro Cioranescu, Santa Cruz de Tenerife, Goya Ediciones, 1978, pp. 201-202.

83 Fr. Juan de Abreu Galindo, Historia de la conquista de las siete islas de Canaria, ed. de Alejandro Cioranescu, Santa Cruz de Tenerife, Goya Ediciones, 1977, p. 87.

${ }_{84}$ Ibid., p. 157.

${ }^{85}$ Es tópico que fijó literariamente el músico Fuenllana (Libro de música para vihuela, intitulado Orphenica Lyra, Sevilla, 1554, fol. 169) en un trístico muy famoso:

Si los delfines mueren de amores, triste de mí, ¿qué harán los hombres que tienen tiernos los coraçones? 
d) Las impresiones de los observadores europeos deben entenderse sobre los canarios de los siglos XVI y XVII, aunque éstos sean "los que descienden de los últimos habitantes" guanches.

e) Aunque las endechas sean comunes a otras islas (Hierro, La Palma, Gran Canaria), los cánticos de los gomeros eran los más "hermosos y dolorosos".

Uno de estos textos, sin embargo, nos da la clave para hablar de romances en Canarias ya, al menos, en el siglo XVII. Es el de Gómez Escudero. Cuando dice que "cantaban canciones sentidas i lastimeras" está repitiendo, indudablemente, el tópico empleado por todos sobre las endechas. Pero cuando a continuación dice que "i repetían una cosa muchas veses a modo de estrivillo", nos está hablando de romances y no de endechas. Porque las endechas no tienen estribillo y sí los romances, tal cual hoy siguen cantándose en las islas occidentales. Así que Gómez Escudero mezcló, ¿inconscientemente?, dos géneros calificándolos con un mismo carácter enternecedor y lastimero.

Interesa insistir en esto, en que la impresión que hoy puede tener cualquier observador del canto de los romances gomeros es la misma que tuvieron los primeros observadores españoles y europeos de los cantos de los canarios del tiempo de la conquista. Más aún: que la única noticia sobre la música de los canarios que nos dejaron los cronistas de la época fue precisamente ésa: la de ser unos cantos lastimeros que "caussan y mueven a compassión y enternesen mucho". Impresión que debió ser intensísima puesto que de forma invariable se constata en cuantos la mencionan. ¿Ello nos autoriza a decir que lo que oímos hoy en La Gomera es lo mismo que oyeron los cronistas de hace cuatro siglos?

La confusión de Gómez Escudero abre interrogantes interesantes en cuanto al origen e implantación de los géneros musicales. en Canarias. Primero: ise trata de dos géneros -endechas y romancesnacidos en Canarias? Segundo: cambos géneros se manifestaban con unas mismas formas musicales? Tercero: ¿qué queda de todo aquello?

Podemos afirmar sin temor a equívoco alguno que los romances que se cantaron entonces y que se cantan ahora en Canarias son los mismos que se cantaron siempre en cualquier lugar de la Península y que, por lo tanto, nada tienen de "guanche". Esto, que puede ser admitido sin discusión, no se puede decir, sin más, de las endechas. Las endechas han pasado siempre por ser género eminentemente canario hasta que estudios recientes han venido a poner en duda creencia tan generalizada. ${ }^{86} \mathrm{Se}$ viene a decir ahora que el fenómeno de las ende-

\$6 Entre los múltiples trabajos dedicados a las endechas canarias destacamos por su relación directa con nuestros planteamientos los de PÉrEz VIDAL (Endechas populares en 
chas hay que vincularlo, seguramente, a la expulsión de los judios españoles en 1492 por los Reyes Católicos y a su diáspora y asentamiento en pequeñas comunidades, en donde se han recogido muestras literarias y musicales que hablan justamente del dolor y sentimiento matizado de un pueblo desarraigado, perseguido y maltratado. $Y$ en Canarias, Lothar Siemens ha aportado un documento que demuestra esa vinculación de los judíos con los descendientes de los canarios aborígenes. ${ }^{87}$ Así que, las endechas son un género español que llegó a Canarias al mismo tiempo que los romances aunque no, seguramente, de igual forma: los romances en boca de los conquistadores, las endechas en el ánimo de los judíos expulsados de la Península que encontraron en Canarias asentamiento más tolerante. No se concibe género tan culto, tan pulido y hasta tan "cortesano", como son las endechas, en un pueblo tan primitivo como el que se encontraron los españoles al llegar a estas islas del Atlántico. Además, ćcómo explicar si no las endechas de Marruecos, Córcega, y Vasconia? Pero, por el contrario, ¿cómo se explican los textos en lengua aborigen de las endechas recogidas por Torriani a fines del XVI? Lo que ocurrió fue que el fenómeno canario -las endechas "de Canarias"- tuvo de pronto un éxito inusitado en la España peninsular de mitad del XVI y que músicos importantes como Pisador, Fuenllana, Bermudo, Vila, Díaz y otros, atraídos por la moda del momento, compusieron endechas "al estilo de Canarias" extendiendo aún más la fama y popularidad de "lo canario". De aquellas endechas no ha quedado ni rastro en la tradición oral de las islas (dudamos que alguna vez llegasen a ser tradición popular) pero sí suficientes muestras en las obras de los músicos españoles del Renacimiento.

De todo ello se deduce que la música de las endechas nada tiene que ver con los romances, como nada tienen que ver tampoco el texto y la estructura métrica particular de cada uno de ellos. Se trata de dos géneros distintos: las endechas lírico, los romances poesía narrativa. Si Gómez Escudero los identificó como una misma cosa, si los cronistas del XVI oyeron las antiguas endechas como hoy podemos oír nosotros los antiguos y modernos romances, es decir, como cantos "que enternesen mucho", es porque quienes los cantaban entonces y los cantan ahora ("y entre todos los gomeros son los que mejor lo usan") lo hacen con un mismo espíritu. Algún rasgo antropológico ha debido pervivir

tristicos monorrimos, siglos XV-XVI, La Laguna, 1952), M. FRENK ALATORRE ("Sobre las endechas en trísticos monorrimos", en Nueva Revista de Filologia Hispánica, XII, Madrid, 1958) y L. SIEMENS HERNÁndez ("Las endechas canarias del siglo xvi y su melodía", en Homenaje a Don Agustín Millares Carlo, II, Las Palmas de Gran Canaria, Caja Insular de Ahorros de Gran Canaria, 1975).

87 L. Siemens, Las endechas canarias, pp. 307-310. 
en las manifestaciones musicales de los gomeros, traspasando el tiempo, para impresionar tanto a quienes en cualquier época los han oído. Salvo esto ¿qué otra cosa del baile del tambor puede decirse que sea autóctona?

Así cantan ahora los romances en La Gomera en el baile del tambor:

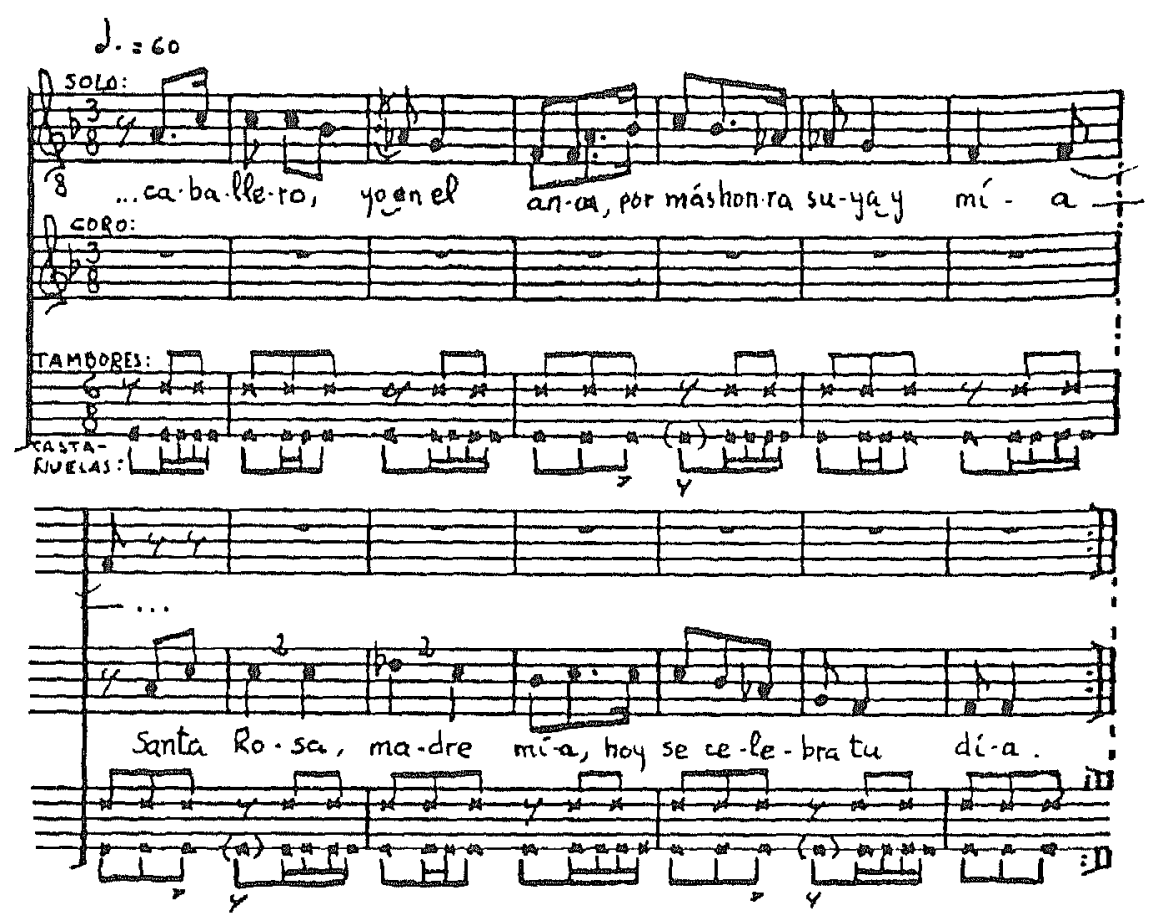

Hemos elegido un romance cualquiera, El caballero burlado en este caso, y no en su comienzo sino en un verso cualquiera del interior para de esta forma mostrar mejor el proceso solista-coro (canto del romance-responder), con sus correspondientes repiques de tambores y de chácaras, en transcripción de L. Siemens Hernández.

Y ésta es la música con que cantan sus coplas los "vaqueiros de alzada" asturianos en el baile del pandero, en transcripción de Torner en $1920^{88}$ (ver página siguiente).

Una comparación de sus estructuras musicales respectivas evidencia unas relaciones más que causales.

${ }^{8 *}$ Cf. su Cancionero, n.o 32. 
88 ad.

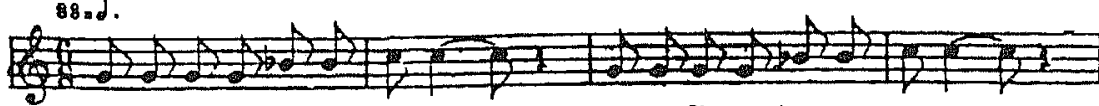

El si. ãar cu . Pa ona bai.la

par que dix que ten co $-90.0 \mathrm{n}$; -

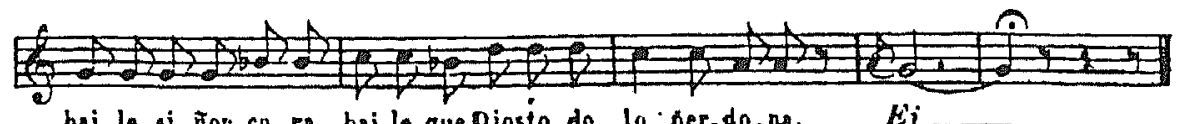

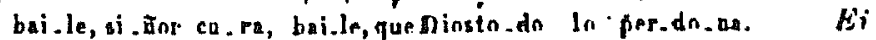

e) El silbo. No es propiamente el silbo un componente del baile del tambor, pero se usa a veces mientras canta el solista para elogiar el canto, al cantador, el baile, a los que bailan o a toda la isla entera. En realidad, nosotros sólo hernos oído silbar al Grupo de Danzas de Hermigua, pero nunca cuando los bailadores eran otros. Así que más bien nos parece una costumbre exclusiva de los de Hermigua, creada por ellos mismos. Pero nada pierde el baile porque no haya silbo.

El silbo gomero tiene importancia excepcional con independencia del baile. Se trata de un auténtico lenguaje articulado -un lenguaje sustitutivo- que sirve como medio de comunicación a los isleños dadas las dificultades enormes que la naturaleza ha puesto a su suelo. El silbo es una especie de teléfono natural, sin hilos, que producido en condiciones favorables permite la comunicación hasta a 3 y 4 kilómetros de distancia. Así, una noticia de interés general puede recorrer de punta a punta toda la isla en muy poco tiempo, siempre que se garantice, claro está, la cadena ininterrumpida de silbadores. Este procedimiento de comunicación humana, que ha hecho a La Gomera famosa en el mundo entero, parece tener raíces prehispánicas, adaptándose luego a la lengua de los conquistadores; pero ha seguido practicándose sin interrupción hasta la actualidad, sin duda debido a la eficacia que demuestra y a la necesidad que los gomeros tienen de él. ${ }^{89}$

89 Sobre el origen y naturaleza del silbo gomero se han escrito y dicho cosas pintoresquísimas: desde que era un sistema de comunicación primitivo que tuvieron que inventar los primeros pobladores de la isla por haberles cortado la lengua, a la lengua conservada de los guanches (con lo que los gomeros hablarian dos lenguas, una para hablar - el español- y otra para silbar -el guanche-), hasta que es un sistema tonal parecido al de los delfines, o un lenguaje cantado. Ramón Trujillo ha venido últimamente a dejar las cosas definitivamente claras con un estudio lingüístico del silbo sirviéndose de un laboratorio de fonética en donde estudió los registros sonoros del silbo: El silbo gomero es un lenguaje sustitutivo, un sistema simplificado del español compuesto por 2 vocales y 4 consonantes. Vid. Ramón TRUJILLo, El silbo gomero, Ed. Interinsular, Santa Cruz de Tenerife, 1978. 


\section{El BAILE DEL TAMBOR, LA ULTIMA DANZA ROMANCESCA}

El baile del tambor es el símbolo de La Gomera, su verdadero himno. Seguramente no hay territorio en España en donde un canto, un baile y una música tengan tal identificación con sus pobladores. En La Gomera el baile del tambor se extiende por igual en toda la isla (aunque naturalmente hay pueblos que reviven con más entusiasmo la tradición) y todos sus habitantes tienen innumerables ocasiones de practicarlo. "Mire usted -nos decía uno de nuestros informantes octogenario-, para mí la única diversión es romanciar, yo cojo mi tambor y me voy a la fiesta y me olvido del mundo". iRomanciar! iHasta han tenido que inventar un verbo inexistente en el español para hablar de sus cosas cotidianas! Es decir, cantar romances, cantar y bailar romances, que eso es el baile del tambor, que eso es "romanciar". Que en la década de los 80 las generaciones adultas (y muchos jóvenes que ahora vuelven los ojos a lo de sus mayores) de un territorio español pasen una fiesta cantando y bailando romances es como volver a un tiempo remoto del que ya no queda memoria por ninguna parte.

Ese extraordinario conservadurismo de sus tradiciones no ha inmovilizado, sin embargo, los textos de los romances que se cantan. Muy al contrario, como ocurre con todos los textos de tradición oral, éstos han evolucionado en un complicadísimo proceso de conservación y recreación adaptándose al momento y al gusto de las generaciones que han usado de ellos. Y esta evolución, como podría pensarse, no es siempre para peor: los textos ganan siempre en poesía y en eficacia narrativa cuando han estado sometidos a un largo proceso de tradicionalización. Ejemplos de romances hemos recogido nosotros en La Gomera que ganan en mucho a los textos que de esos mismos romances recogieron los antologistas del XVI, con ser aquel siglo verdaderamente áureo en la historia del romancero tradicional. $Y$ es que el cantor gomero, a la vez que ha heredado de sus antepasados un repertorio de romances extraordinario, ha heredado también los mecanismos y el lenguaje que únicamente los auténticos autores tradicionales poseen. No es una cuestión de aprendizaje en escuelas y libros, es sólo una cuestión de vida, de vivencias cotidianas desde la infancia, un modelo de lenguaje que forma parte del aprendizaje inconsciente de la tradición.

La pervivencia de un baile romancesco es un arcaísmo venerable, pero lo es más aún el que ese medio de transmisión y recreación que en La Gomera es el canto y el baile haya propiciado la conservación del excepcional repertorio romancístico que alli vive. Seguramente, y comparado en sus justos términos, el fenómeno de La Gomera no 
Plc. 9. El tambor y las chaca. ras son los instrumentos tipicos del baile del tambor de La Gomera. Prudencio y su mujer Dolores, de El Cedro, los tocan para nosotros en 1983. (Foto del autor)
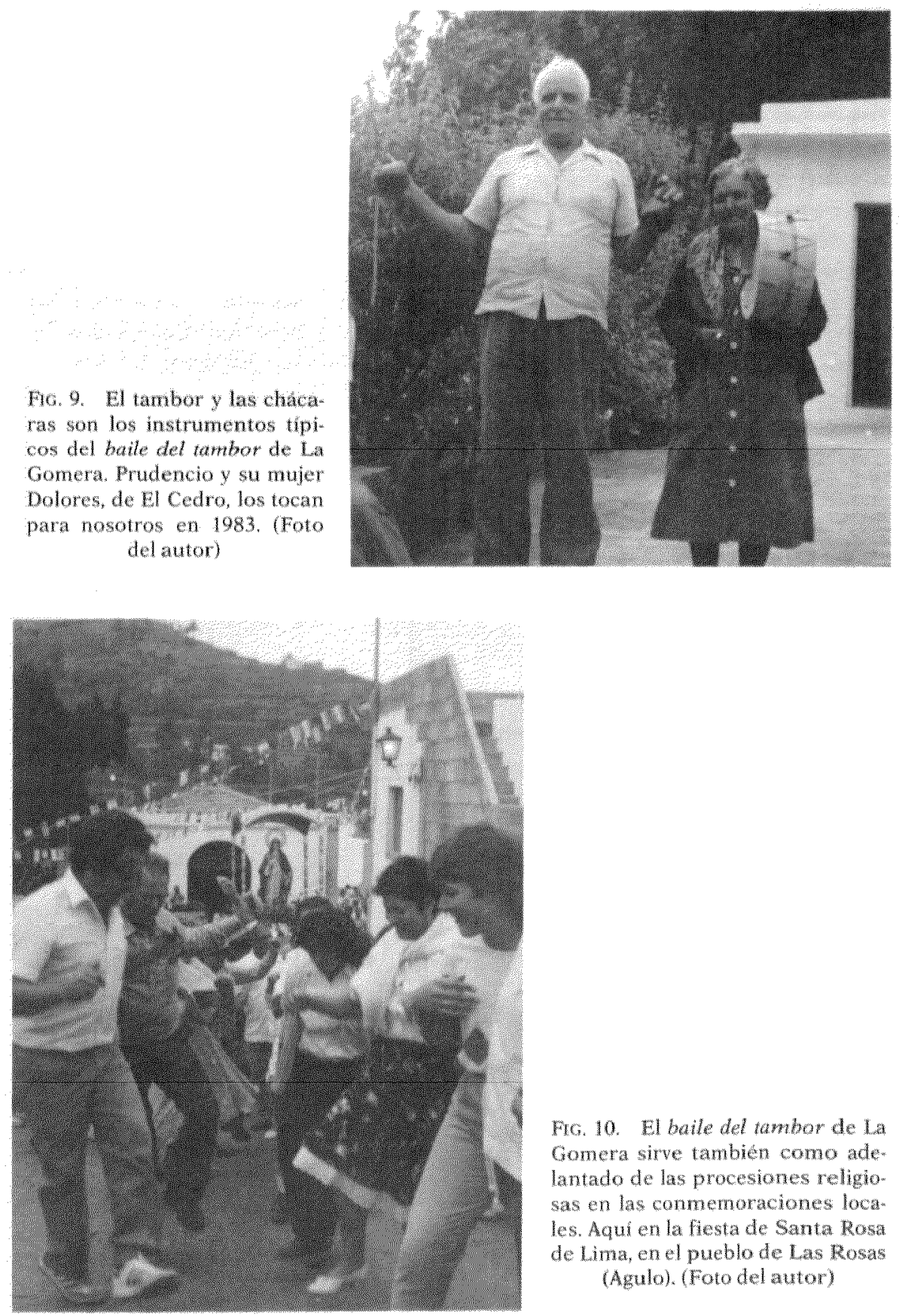

Fic. 10. El baile del tambor de Lat Gomera sirve tambien como ade. lantado de las procesiones religiosas en las conmemoraciones loct les. Aqui en la fiesta de Santa Rosa de Lima, en el pueblo de Las Rosas (Agulo). (Foto del autor) 
tiene parangón en el resto de los territorios españoles e hispánicos en donde el romancero oral ha llegado hasta hoy, incluidas las comunidades judías sefarditas del Norte de África y de la Europa Oriental que han sido siempre las más conservadoras. En otros sitios habrá romances más antiguos, y hasta es posible que más variados, pero ningún otro lugar presenta un panorama tan uniforme como La Gomera, ningún otro en donde la tradición vive con tanta intensidad, ningún otro en donde el repertorio abarca límites tan extensos, ningún otro, desde luego, en donde el romancero cumpla una función social y festiva tan importante. El romancero es un accidente más de la geografía de La Gomera, de la geografía humana, claro está, un garajonay que en siglos y generaciones se ha adueñado de todos los isleños para que los de hoy repitan como los de antaño: "viejos son pero no cansan". 